\title{
El agrarismo rojo de las llanuras duranguenses. Movilización campesina y represión política en 1929
}

César Navarro Gallegos

INSTITUTO MORA

\begin{abstract}
Al finalizar los años veinte, en Durango prácticamente seguía intacto el régimen de propiedad de la tierra en manos de la oligarquía porfirista. El reparto de los grandes latifundios se hacía a cuentagotas y mediante lentos y complicados trámites. Ello originó un movimiento radical que nucleó las luchas agrarias de miles de campesinos durangueños. Los conflictos políticos de 1929, tanto nacionales como locales, definieron la existencia misma de este precursor agrarismo del siglo xx en la entidad.
\end{abstract}

$\mathbf{L}$

a creación del Partido Nacional Revolucionario, en 1929, entrañó un conjunto de alteraciones y cambios definitorios para la vida política del país, especialmente en relación con el funcionamiento y las prácticas políticas del "bloque revolucionario" en el poder. En primer término, abrió paso a la incorporación dentro de una misma organización política al vasto conglomerado de caciques, líderes y jefes militares que se reconocían a sí mismos como integrantes de la "familia revolucionaria", al igual que de las organizaciones y partidos políticos de los que éstos eran je- fes. Simultáneamente se presentó como una coyuntura oportuna para eliminar o depurar de sus propias filas a un buen número de líderes y jefes reacios a someterse al nuevo sesgo y reglas políticas que se imponían dentro del régimen político posrevolucionario.

En segundo término, la formación del Partido Nacional Revolucionario representó para sus artífices el inicio del proceso de "institucionalización" del régimen político de la revolución mexicana. Sin embargo, la creación del nuevo partido distó de ser un genuino aporte para que las instituciones del 
estado, derivadas del régimen constitucional implantado en 1917 , funcionaran efectivamente como tales. Al respecto bastaría con señalar cómo el PNR sirvió de sustento para consolidar el poder político del "maximato callista" y, por tanto, para prolongar la existencia de un poder dual en el interior del régimen político, en el que el "hombre fuerte" o "jefe máximo de la revolución" pudiera disponer de un poder suprainstitucional. No obstante, habría que reconocer que el principal aporte del PNR fue su contribución para unificar y disciplinar a los dispersos segmentos de la "familia revolucionaria" y consolidar su condición de fracción de clase en el poder.

Por otra parte, el proceso de integración de la "familia revolucionaria" en un solo partido significó la virtual exclusión de otras fuerzas sociales y políticas en el ejercicio del poder estatal. Muy pronto el PNR se convertiría en una maquinaria de dominación política a la que en adelante ninguna fuerza estaría en condiciones de enfrentar con éxito. ${ }^{1}$ Pese a que los principales promotores y organizadores del Partido de la Revolución Mexicana reconocieron la existencia de fuerzas adversas u opositoras al proyecto revolucionario y el derecho de éstas para organizarse políticamente y hasta se les conminó para que integraran sus respectivas agrupaciones con el fin de que disputaran el poder por la vía pacífica y electoral, en la práctica, con el surgimiento del PNR, se fueron sentando las bases para la ulterior conformación de un régimen político de partido úni-

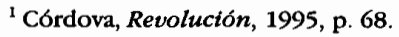

co y de Estado que monopolizó y, en muchas ocasiones, secuestró la representación política de la sociedad mexicana durante más de medio siglo.

La idea de organizar el "partido de la revolución" se esbozó públicamente en el mensaje político que el presidente Plutarco Elías Calles dirigió al Congreso de la Unión durante su último informe de gobierno ( 1 de septiembre de 1928) al anunciar y perfilar el advenimiento de un régimen democrático y plural en el que las distintas fuerzas sociales y grupos políticos organizados dispondrían de espacios para su participación y representación; al afirmar que

este templo de la ley [el Congreso] parecerá más augusto y ha de satisfacer mejor las necesidades nacionales, cuando estén en esos escaños representadas todas las tendencias y todos los intereses legitimos del país

y en la medida en que mediante el "respeto al voto" los indiscutibles representantes de los trabajadores del campo y la ciudad, de las clases medias, de los intelectuales y "hombres de todos los credos y matices políticos de México, ocupen lugares en la representación nacional, en proporción a la fuerza que cada organización o cada grupo social" logre conquistar. ${ }^{2}$

La incitación callista, expresada todavía en el marco de las turbulencias derivadas de la crisis política que estalló tras la eliminación del caudillo sonorense Álvaro Obregón, comprendía a todas las vertientes políticas del país, incluidos reaccionarios y conservadores, pues-

\footnotetext{
${ }^{2}$ Elías, Exposición, 1928, p. 11.
} 


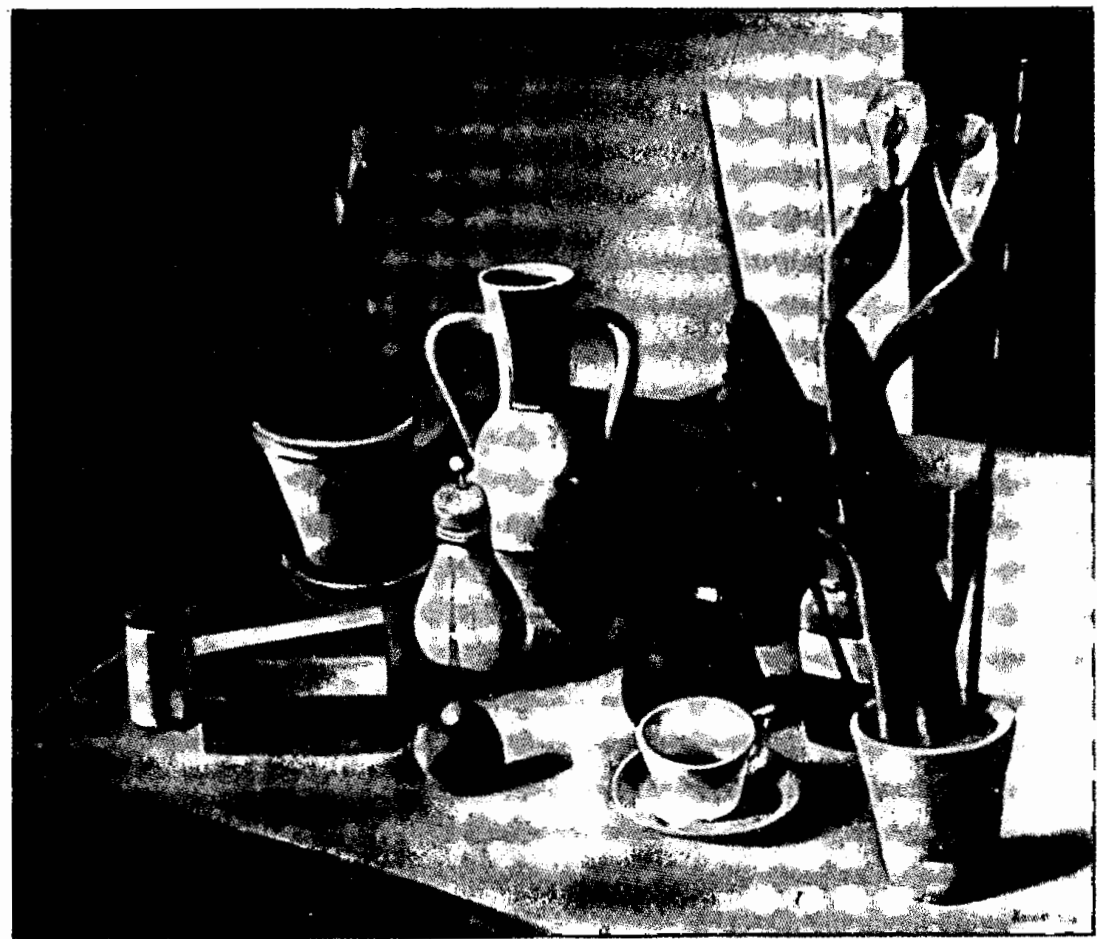

to que proponía que la república debía arribar de manera definitiva al campo de las instituciones, las leyes y al establecimiento de verdaderos "partidos nacionales orgánicos, con olvido e ignorancia, de hoy en adelante, de hombres necesarios como condición fatal y única para la vida y tranquilidad del país". 3

${ }^{3}$ Ibid., p. 14. Por supuesto, no todos los integrantes de la "familia revolucionaria" otorgaron credibilidad al mensaje de Calles, ni aceptaron someterse a su proyecto; la revuelta militar que estallaría unos meses después encabeza-
Al cabo de unos meses del mensaje del 1 de septiembre de 1928, se darían los primeros pasos para concretar uno de los objetivos del proyecto delineado por Calles, al convocarse a la asam-

da por un grupo de antiguos obregonistas daría cuenta de la oposición dentro de las propias filas revolucionarias. El más inmediato, y en cierto modo profético cuestionamiento a su iniciativa, fue la expresión de ifarsante!, que le lanzara el diputado obregonista Aurelio Manrique al final de su mensaje del 1 de septiembre de 1928 . Véase El Universal, 2 de septiembre de 1928. 
blea constituyente del partido que agruparía a las fuerzas de la revolución. El nuevo agrupamiento político: el Partido Nacional Revolucionario, quedó formalmente constituido luego de la convención celebrada del 1 al 4 de marzo de 1929 en la ciudad de Querétaro. Asimismo, la emergente organización inaguró su ingreso en la vida política nacional postulando como candidato presidencial para las elecciones que se celebrarían en diciembre de ese mismo año a Pascual Ortiz Rubio.

Sin embargo, las promesas de Calles y del bloque de líderes y jefes revolucionarios agrupados en el PNR, en relación con el inicio de una nueva etapa política para el país caracterizada por el respeto a la ley, la observancia de los principios democráticos, la institucionalidad, la pluralidad y la tolerancia política, fueron incumplidas. Ello quedó evidenciado a través del hostigamiento, persecución y violencia con que se trató a las fuerzas sociales y organizaciones partidarias que se resistieron a sumarse al PNR, o que pretendieron contender electoralmente en oposición a éste.

Por supuesto que estos señalamientos no se refieren, ni incluyen la revuelta militar "escobarista", que estalló (3 de marzo de 1929) cuando en Querétaro se fundaba el PNR, encabezada por un reducto de oficiales del ejército pertenecientes a la corriente obregonista y que intentó oponerse al encumbramiento de Calles como jefe indiscutido del "sanedrín" revolucionario, a la formación del PNR, pero sobre todo a la designación del candidato presidencial que aquél había impuesto.

Nos referimos a la postura asumida desde el poder estatal y el naciente par- tido oficial hacia los agrupamientos políticos que intentaron mantener su propia sistematización, incluidos aquellos que hasta entonces habían sido reconocidos como destacamentos de la corriente revolucionaria. Así, tras el surgimiento del PNR se desató una persistente campaña para erosionar y fracturar la fuerza política que habían alcanzado, al amparo del propio régimen revolucionario, partidos como el Laborista Mexicano, dirigido por la fracción "cromista" de Luis N. Morones, y el Nacional Agrarista acaudillado por Antonio Díaz Soto y Gama y Aurelio Manrique, antiguos aliados del obregonismo; campaña que culminaría con el declive y virtual extinción de esas formaciones políticas.

Empero, donde se evidenció con mayor transparencia la exclusión e intolerancia política que emergió a la par del naciente proyecto "institucionalizador" y la creación del PNR, fue en la coyuntura electoral de 1929. En la práctica, el PNR impidió que la campaña presidencial se desarrollara en el marco de una contienda democrática. El pecado de origen del PNR consistió en su rechazo a enfrentar y contender electoralmente como un verdadero partido. Amparado en su concepción originaria de instrumento de Estado, enfrentó el desafio electoral de otras fuerzas políticas desde la óptica de su eliminación o derrota, a través de todos los medios y recursos puestos a su disposición, así fuesen legales o ilegales.

Por ende, la campaña opositora desplegada por el Partido Nacional Antirreeleccionista (PNAR), con José Vasconcelos como su candidato presidencial, no sólo fue objeto de la descalificación 
y condena política, sino que debió enfrentar un cúmulo de arbitrariedades y agresiones de las hordas y caciques del PNR. A lo largo de la campaña electoral un buen número de mítines y actos públicos fueron hostilizados o disueltos, y centenares de sus partidarios fueron encarcelados. Asimismo, durante el proceso electoral, y hasta su conclusión, decenas de vasconcelistas fueron asesinados. De esta manera la crítica vasconcelista hacia el autoritarismo callista y sus cofrades, los señalamientos en torno a las desviaciones impuestas al proyecto de la revolución y su demanda por el restablecimiento del precursor principio de "no reelección", fueron prácticamente acallados por la ruidosa y estentórea pero vacua campaña electoral del PNR, así como por la represión. ${ }^{4}$

Sin embargo, el flanco al que se dirigió con mayor fuerza y agresividad el golpe represivo desatado en la primavera de 1929 fue hacia la izquierda comunista y las organizaciones campesinas y obreras que se habían nucleado en torno al llamado Bloque Obrero y Campesino (BOC). Este frente político se había constituido por iniciativa de la Liga Nacional Campesina y el Par-

\footnotetext{
${ }^{4}$ Algunos autores explican el comportamiento autoritario y la actitud represiva del PNR en la contienda electoral de 1929 en razón de su inexperiencia partidaria y sus dudas y temores electorales. Véase Meyer, Segovia y Lajous, Historia, 1981, vol. 12, p. 104. Creemos, sin embargo, que tal explicación resulta insuficiente. Pensamos que la clave de tal cuestión debiera buscarse en el proceso de integración y disciplina de la familia revolucionaria, en la centralización del poder "callista" y en el viraje conservador del régimen de la revolución mexicana.
}

tido Comunista de México, con el propósito de conjuntar y hacer partícipes en la campaña electoral a distintas fuerzas que enarbolaban los principios socialistas y orientaban su lucha política desde una perspectiva revolucionaria y de clase. El Bloque se había dispuesto a contender en la campaña electoral designando como candidato presidencial al general Pedro Rodríguez Triana, hombre que en otros tiempos había luchado en las filas magonistas, posteriormente al lado del zapatismo y que para entonces militaba en la Liga Nacional Campesina. $^{5}$

Luego de su participación al lado del gobierno en el aplastamiento de la rebelión escobarista, las organizaciones integradas en el BOC fueron perseguidas y reprimidas por el gobierno y el ejército bajo el supuesto de que pretendían organizar un alzamiento o complot revolucionario, mediante el cual se implantaría un gobierno obrero-campesino y un régimen de corte "bolchevique". 6 La cacería política en contra de los comunistas y las organizaciones del Bloque desembocó en la represión, encarcelamiento y fusilamiento de múltiples de sus dirigentes y militantes. La LNC sería fracturada y algunos de sus residuos, captados por el PNR; se decretaría la prohibición para la publicación de la prensa comunista, y la Confederación Sindical Unitaria de México y el Partido Comunista serían declarados ilegales, obligándolos a pasar a la vida clandestina durante varios años. ${ }^{7}$

\footnotetext{
${ }^{5}$ Martínez, Historia, 1985, pp. 94-95.

${ }^{6}$ Ibid., pp. 114-117.

${ }^{7}$ Como es de suponer, la persecución hacia los miembros y organizaciones del Bloque impidió la continuación de su campaña electoral.
} 
En medio de este "apacible y democrático" entorno, el PNR se alzó como el indiscutido vencedor en las elecciones presidenciales de 1929. Bajo esta estela de ilegalidad, impunidad y criminalidad habría de iniciarse la larga permanencia del PNR y sus partidos sucedáneos en la vida política nacional. ${ }^{8}$

A partir de este conjunto de hechos y acontecimientos políticos que enmarcan el inicio del periodo del "maximato callista", nos proponemos describir y abordar el impacto que regionalmente tuvo la persecución y represión de los comunistas y de las organizaciones dirigidas por éstos en la entidad duranguense. Los acontecimientos ocurridos en Durango, en esa coyuntura, han sido puestos de relevancia, sin excepción alguna, en todos los trabajos y textos de corte histórico y político destinados al estudio de este periodo, ya que justamente en Durango arranca la represión hacia las organizaciones sociales, principalmente agrarias, vinculadas a la Liga Nacional Campesina y a la Confederación Sindical Unitaria de México, y también donde inicialmente fueron encarcelados y ejecutados varios dirigentes comunistas.

En distintas obras de carácter testimonial, así como en algunos textos y estudios históricos, se ha señalado que lo ocurrido en Durango determinó en gran medida la postura que el gobier-

\footnotetext{
${ }^{8}$ Según los resultados oficiales de la elección presidencial, el candidato del PNR, Pascual Ortiz Rubio, fue declarado vencedor por una amplia mayoría, asignándosele 1825732 votos. En tanto que a Vasconcelos y a Rodríguez Triana les fueron reconocidos 105655 y 19665 votos respectivamente. Véase Garrido, Partido, 1985, p. 110.
}

no nacional asumiría a lo largo de ese periodo ante los movimientos sociales y las fuerzas políticas de la izquierda mexicana, a la vez que por contraparte influyó de manera significativa en la estrategia política que los comunistas, y un sector importante del movimiento obrero y campesino, adoptarían frente al "maximato" y el PNR. Otro aspecto que igualmente destacan es el relativo a sus efectos en la política externa y las relaciones diplomáticas de nuestro país, puesto que se considera que el conflicto duranguense fue el detonante de una serie de fricciones y reclamaciones entre México y la Unión Soviética que derivarían al poco tiempo en la ruptura de las relaciones diplomáticas entre ambos países. ${ }^{9}$

Historiar ahora este proceso desde su dinámica regional nos remite a la exposición de una serie de hechos relativos al comportamiento e influencia que ejercieron las elites o grupos de poder económico y político local en el desarrollo de estos acontecimientos y conflictos; al proceso de conformación de la corriente comunista y de las organizaciones, a través de las cuales llegó a

\footnotetext{
${ }^{9}$ Entre las obras de tipo testimonial que nos parecen más relevantes están aquellas cuyos autores estuvieron vinculados directa o indirectamente a los sucesos duranguenses, en tal sentido destaca lo escrito por Emilio Portes Gil, en ese tiempo presidente interino del país; las memorias de Jesús Silva Herzog, entonces embajador mexicano ante la URSS, y las del militante comunista Valentín Campa Salazar. Véase. Portes, Quince, 1941; Silva, Vida, 1993; Campa, Testimonio, 1978. En cuanto a la historiografia sobre este tema, además de las obras que aparecen citadas en el presente artículo, destacaríamos: Carr, Movimiento, 1981; Córdova, Clase, 1981; Peláez, Partido, 1980.
} 
adquirir una destacada presencia social y política en la entidad, así como a delinear los factores y circunstancias que incidieron en el entorno regional para la adopción de las drásticas medidas que el gobierno puso en práctica para decapitar la oleada roja que se extendía por los valles y llanuras de Durango.

\section{EL COMUNISMO DE LOS LIANOS}

Y EL MALPAÍS. BROTES ORGANIZATIVOS

Y GERMINACIÓN DE LAS LUCHAS DE LOS AGRARISTAS ROJOS DE DURANGO

Entre los años de 1925 y 1929 , un creciente número de campesinos agraristas de Durango se organizaron y desplegaron sus luchas enarbolando las banderas rojas con el emblema de la hoz y el martillo. Los principales destacamentos de este renovado movimiento agrario brotaron de entre los pueblos, rancherías y comunidades que, apenas unos años atrás, se habían alzado como bastiones del villismo y aportado importantes contingentes para el ejército acaudillado por el revolucionario durangueño y, que más tarde, cuando sobrevino la derrota y declinación de la División del Norte, constituyeron núcleos de apoyo y base social para la resistencia de la guerrilla villista. De esta manera, una década después, en los mismos valles y semiáridas regiones por donde se extendió la rebelión agraria encabezada por los revolucionarios villistas, ésta encontró continuidad en la lucha de los jornaleros, peones y campesinos agraristas que reclamaban la destrucción del latifundio, el reparto de la tierra entre los pobres y que además ahora se proponían luchar para construir una sociedad sin propietarios y sin explotados.

La presencia política e influencia social alcanzadas por la izquierda comunista fue el resultado de un persistente trabajo propagandístico y organizativo desarrollado entre las masas campesinas y obreras durante esos años, a través del cual logró arribar a la dirección de la Confederación de Sindicatos Obreros y Campesinos de Durango, y pudo concretar la fundación de su propia organización política regional: el Partido Durangueño del Trabajo. A ello se sumó el liderazgo de las organizaciones gremiales de los trabajadores ferrocarrileros y la conducción de los partidos políticos locales en los que militaban la mayoría de los ferrocarrileros duranguenses: el Partido Revolucionario Ferrocarrilero de Durango y el Partido Ferrocarrilero Unitario de Gómez Palacio, filiales ambos del Partido Ferrocarrilero Unitario, con sede en la ciudad de México y dirigido por el líder comunista Hernán Laborde.

Aun cuando el Partido Comunista ${ }^{10}$ surgió en Durango desde noviembre de 1921, al constituirse la "local"11 respectiva con la participación inicial de un reducido grupo de panaderos y maestros, ${ }^{12}$ su transformación en una

${ }^{10}$ En relación con los orígenes y formación del Partido Comunista de México (1919), pueden consultarse los textos ya citados de Martínez Verdugo y Gerardo Peláez, así como los de Taibo II, Bolsbevikis, 1986; Neymet, Cronologia, 1981, y Carr, "Orígenes", entre otros.

${ }^{11}$ De acuerdo con la estructura orgánica del PC, éste se organizaba a través de secciones locales, las cuales dentro del "argot" partidario eran conocidas como las "locales". En este caso la "local" de Durango.

12 Taibo II, Bolshevikis, 1986, p. 145. 
organización con influencia entre las masas campesinas y trabajadoras ocurrió a mediados de la década de los años veinte, al incorporarse al partido un importante núcleo de luchadores sociales integrado por un puñado de jóvenes profesores rurales y un reconocido grupo de líderes agraristas, originarios mayoritariamente de pueblos de la "región de los llanos" y en el que también confluyeron varios dirigentes ferrocarrileros de la entidad.

La influencia social que este núcleo había alcanzado -sorteando y enfrentando la oposición y persecución de hacendados, terratenientes y caciquesentre amplios grupos de campesinos y trabajadores agrícolas a los que habían organizado en numerosos sindicatos y comités agrarios en demanda del reparto de tierras y la formación de ejidos, facilitó la incorporación de importantes contingentes de trabajadores y campesinos en las organizaciones sociales y políticas dirigidas por los comunistas. Entre los principales impulsores y dirigentes de la corriente roja duranguense destacaban los líderes agraristas Fortino H. Aragón, Sixto Fernández, Salvador Garay, Lorenzo Gutiérrez, Santos Marrero, así como el joven profesor rural José Guadalupe Rodríguez, quien se había erigido en el principal ideólogo, organizador y líder de los comunistas duranguenses. ${ }^{13}$

\footnotetext{
${ }^{13}$ Fortino H. Aragón había encabezado la lucha por el reparto de tierras para los campesinos de Villa Ignacio Allende del municipio de Peñón Blanco, por lo que se le designó presidente de su Comité Agrario. Fue, asimismo, uno de los organizadores de la Federación de Sindicatos de Obreros y Campesinos de la Región Llanera y miembro fundador del Partido
}

El trabajo organizativo desplegado por la corriente roja entre las masas campesinas y trabajadoras rindió sus primeros frutos en 1925 al conquistar la dirección de la Confederación de Sindicatos Obreros y Campesinos de Durango (CSOC), organización entonces adherida a la Confederación Regional de Obreros de México (CROM). Bajo la conducción de los comunistas, la Confederación puso fin a la tutela y el contubernio político hasta entonces mantenidos con los gobiernos locales, a la vez que fue distanciándose de las directrices impuestas dentro de la CROM por el corrompido liderazgo de Luis $\mathrm{N}$.

Durangueño del Trabajo, del cual llegó a ser secretario general. Sixto Fernández era originario del pueblo de Calixto Contreras, perteneciente también al municipio de Peñón Blanco; organizador y dirigente del Sindicato de Obreros y Campesinos "Felipe Carrillo Puerto" de dicha población y promotor también de la federación llanera. Al conquistar la corriente roja la dirección de la Confederación de Sindicatos de Obreros y Campesinos de Durango fue electo secretario general estatal. Por su parte, J. Guadalupe Rodríguez, quien era originario de la ciudad de Dúrango, primero se desempeñó como maestro rural en algunos municipios del sur del estado (Vicente Guerrero, Súchil y Poanas) en donde se vinculó a la lucha agraria de los campesinos de esa región. En representación de campesinos y sindicatos agraristas de Durango asistió a varias reuniones y congresos campesinos celebrados en distintos lugares del país, a través de los cuales entró en contacto con los dirigentes de las ligas agrarias y campesinas de otras entidades y militantes del PCdeM, organización política a la que se afilió en 1924 . Fue el principal organizador y dirigente del Partido Durangueño del Trabajo, del que también fue secretario general. A partir de 1926 Guadalupe Rodríguez formó parte del Comité Central del PCdem. En 1927 asistió como delegado de la LNC al congreso de la Internacional Campesina Roja celebrado en Moscú. 


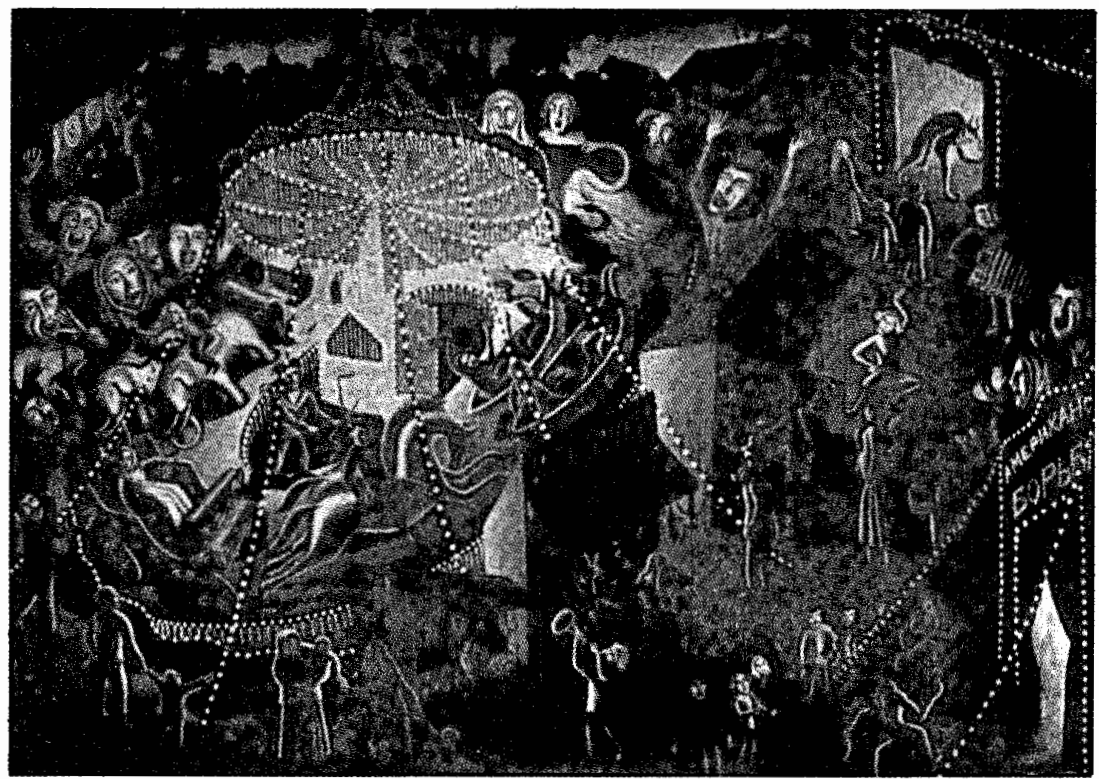

Morones y su grupo Acción. En la medida que radicalizó sus estrategias de lucha e hizo suyas de manera efectiva las demandas del campesinado pobre de Durango, pronto se convirtió en la principal organización de masas de la entidad, llegando a agrupar bajo sus siglas a varias federaciones regionales, un importante contingente de sindicatos obreros y campesinos, así como decenas de comités agrarios ${ }^{14}$ (véase cuadro 1 ).

${ }^{14}$ Boletín de la Séptima Convención de Obreros y Campesinos de Durango. Gómez Palacio, Dgo., 6 de abril de 1927, Archivo General de la Nación (en adelante AGN), fondo Obregón-Calles, exp. 205-G-54.
La creciente movilización por el reparto de tierras desplegada por los contingentes campesinos agrupados en la Confederación, requirió de la solidaridad e hizo necesarias la convergencia y unidad de acción con otros agrupamientos campesinos del país, así como de la propia entidad. Por ende, la Confederación de Sindicatos Obreros se sumó al llamado que inicialmente hiciera la Liga de Comunidades Agrarias de Veracruz y que más tarde retomaron las ligas campesinas que surgieron en otras entidades (Michoacán, Morelos, Oaxaca y México), en el sentido de avanzar hacia la constitución de una organización nacional de los campesinos de México. Al concretarse dicha 


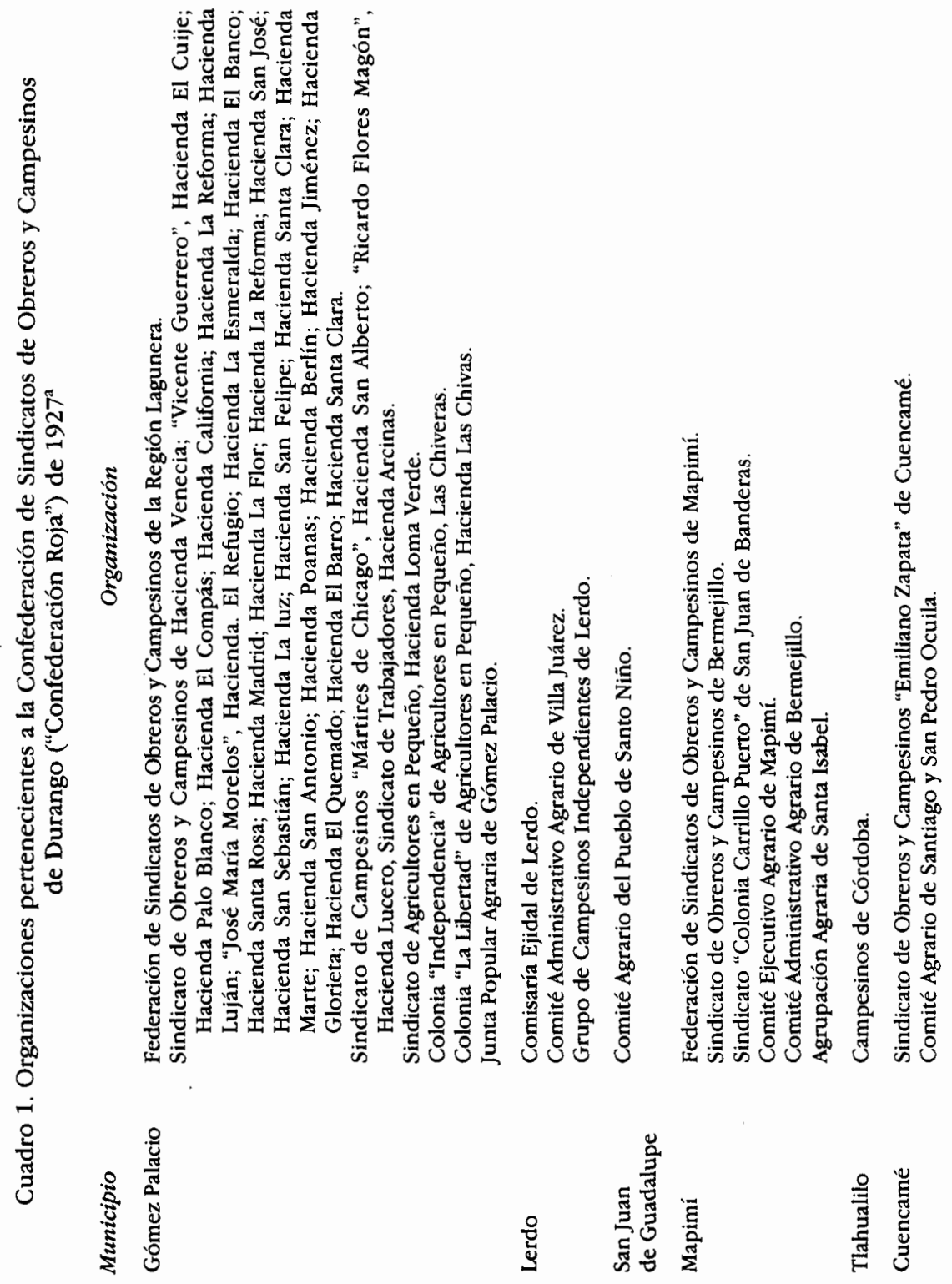




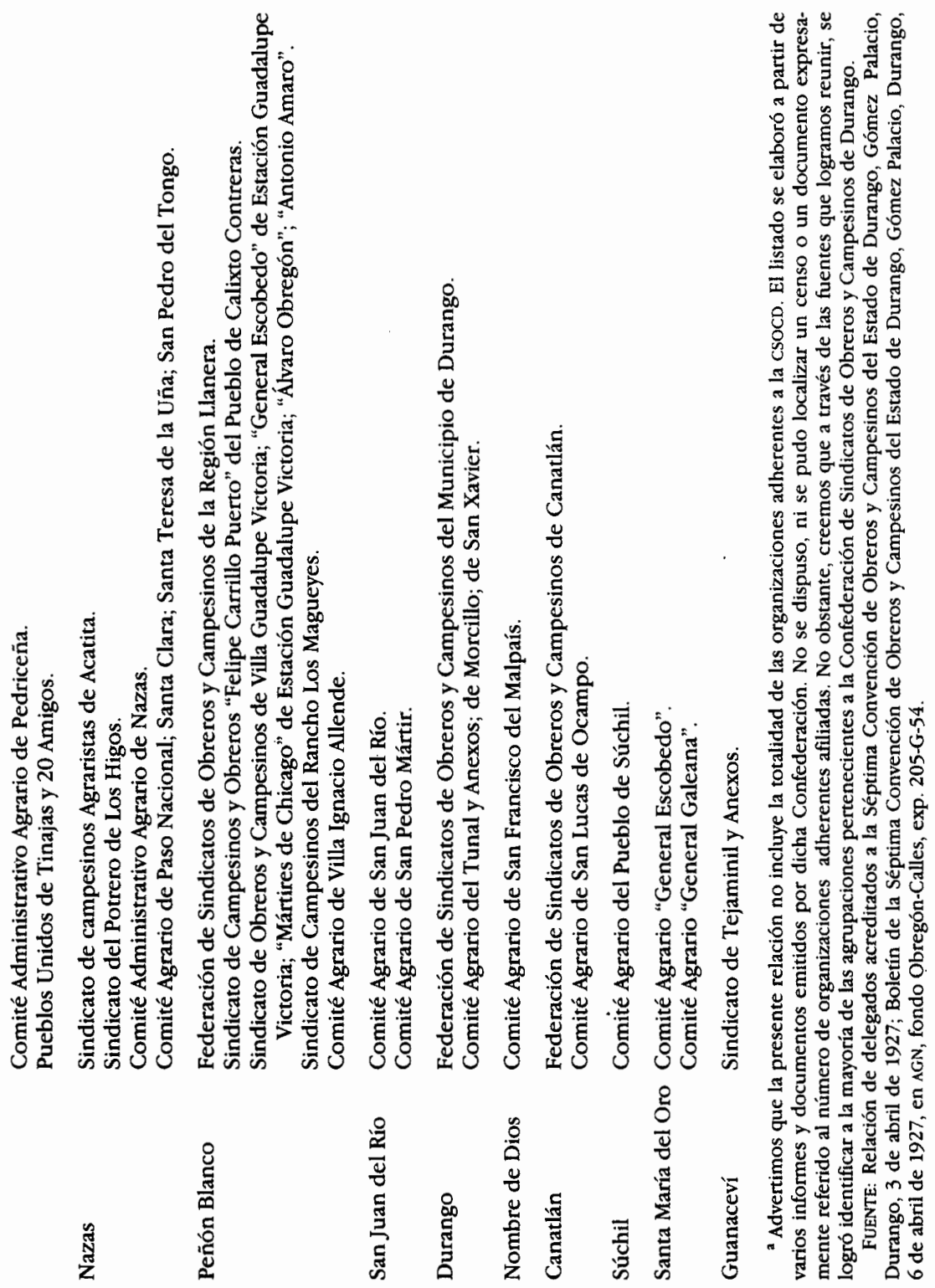


iniciativa, impulsada centralmente por los contingentes y líderes campesinos pertenecientes al Partido Comunista, así como por otros dirigentes agraristas de la talla de Adalberto Tejeda y Francisco Mújica, la confederación duranguense participó en la promoción y organización del congreso de unificación de las organizaciones campesinas del país en el que surgió la Liga Nacional Campesina en 1926.

La dimensión y relevancia adquiridas por el movimiento de los agraristas duranguenses se evidenció en el congreso constitutivo de la LNC: la Confederación de Obreros y Campesinos de esa entidad destacó entre las organiżaciones que aportaron los contingentes más numerosos y representativos para la construcción de la nueva central. Igualmente fueron reconocidos el compromiso y trayectoria dentro de la lucha agraria del joven dirigente comunista José Guadalupe Rodríguez. Al conformarse la directiva de la LNC, el profesor rural y dirigente campesino norteño resultó electo integrante de su primer comité nacional a cuyo frente estaban los prestigiados líderes campesinos Úrsulo Galván, presidente, y Manuel $P$. Montes, secretario y, junto a ellos como tesorero, J. Guadalupe Rodríguez. ${ }^{15}$

De esta manera, al incorporarse la confederación duranguense a la Liga Nacional Campesina, contribuía al primer intento por la unificación autónoma del movimiento campesino del país y pasaba a formar parte del contingente que por su programa y objetivos sociales constituía la expresión más avan-

\footnotetext{
${ }^{15}$ Martínez, Historia, 1985, p. 84.
}

zada y progresista del agrarismo mexicano.

Mientras tanto, la estrategia unitaria desarrollada regionalmente por los agraristas "rojos" condujo a la alianza con el Sindicato de Campesinos Agraristas del Estado de Durango en el año de 1927. Esta organización había sido fundada desde 1920 bajo el nombre de Sindicato Agrario Confederado de Durango y luego, al celebrarse en el año de 1922 el Segundo Congreso Agrarista en la población de Guadalupe Victoria, adoptó su nueva denominación. Dicho sindicato era reconocido como la primera agrupación o central agraria surgida en Durango en el periodo posrevolucionario. ${ }^{16}$ Su fundador y principal líder era el abogado duranguense Alberto Terrones Benítez, diputado al Constituyente de 1917, el cual se mantenía en la presidencia del sindicato desde su conformación. A través del liderazgo del sindicato, integrado básicamente por grupos de campesinos solicitantes de tierra, Terrones Benítez se había hecho de una amplia base social que le sirvió para encumbrarse como uno de los personajes políticos más influyentes dentro de la "familia revolucionaria" duranguense. ${ }^{17}$

${ }^{16}$ Declaración del Sindicato de Campesinos Agraristas de Durango. Durango, 29 de abril de 1927, AGN, fondo Obregón Calles, exp. 205G-54.

${ }^{17}$ En los años posteriores a su paso por el Congreso de 1917, Terrones Benítez ocupó varios cargos como funcionario de los gobiernos federal y local. Asimismo, retornó al Congreso de la Unión en dos ocasiones más: primero como diputado federal en 1922 y luego como senador en 1924. También fundó en 1926 y dirigió el Partido Socialista del Estado de Durango. 
En la práctica, el sindicato dirigido por Terrones constituía la organización agraria "oficialista" y, no obstante la radicalidad de su lema: "La tierra por la ley o por la fuerza" y la fraseología "revolucionaria" y "socialista" de la que estaban impregnados sus documentos y el discurso de sus líderes, la acción del sindicato era de franca moderación y conducida dentro de los límites y trámites impuestos por la legislación respectiva $\mathrm{y}$, por supuesto, siempre a tono con la política agraria del régimen en turno. En realidad, desde sus inicios había funcionado como un instrumento de contención para las crecientes exigencias agrarias de miles de campesinos y como freno a la radicalización de sus luchas para hacer efectivo su derecho a poseer la tierra.

Luego entonces ícómo explicar el acercamiento político y el pacto de unidad establecido entre el sindicato agrarista de Terrones Benítez y la Confederación en el año de 1927? ¿Qué circunstancias e intereses políticos hicieron confluir al movimiento encabezado por el ex constituyente con la Confederación "colorada"? Una primera explicación se encuentra vinculada al hecho de que para entonces el sindicato de Terrones había perdido gran parte de su antigua fuerza y por consiguiente había sido desplazado del liderazgo y la conducción del movimiento agrarista por los confederados. Ante el debilitamiento de su organización y la perspectiva de que sus mermadas bases terminaran por ser atraí-

Sus actividades políticas y sindicales se complementaban con sus negocios como inversionista y perito minero y su desempeño como litigante. das por la confederación "roja", Terrones prefirió unirse a J. Guadalupe Rodríguez y su grupo para resguardar de algún modo parte de su desgastado liderazgo social. Pero sin duda, el elemento determinante que estaba detrás de la postura asumida por el abogado duranguense lo constituía su añeja aspiración política de alcanzar la gubernatura de la entidad, cargo al que había pretendido en más de una ocasión en coyunturas electorales anteriores. A través de dicha alianza el político duranguense estimaba contar con el apoyo del movimiento obrero y campesino y de sus organizaciones políticas para su postulación como candidato a gobernador en las elecciones de 1928.

Por su parte, la alianza significaba para los "confederados" ampliar su base social y extender su radio de acción a otras regiones de la entidad, a la vez que se acrecentaba y reforzaba su proyecto organizativo. Representaba, asimismo, la consolidación de su dirección política entre el proletariado y los campesinos duranguenses: brecha necesaria para abrir el camino y continuar con la siembra de las ideas sobre la revolución proletaria y el socialismo. Además, mediante la alianza con Terrones se ampliaba en la entidad la base social perteneciente a la Liga Nacional Campesina ${ }^{18}$ Bajo estas

${ }^{18}$ Todavía en 1927 la Confederación de Sindicatos Obreros y Campesinos de Durango se mantenía oficialmente adherida a la CROM. Sin embargo, sus nexos eran cada vez más de carácter formal. Como se ha señalado, la Confederación también formaba parte de la Liga Nacional Campesina desde su fundación en 1926. En realidad, con esta organización, dirigida por los comunistas y otras corrientes agraristas radicales, 
circunstancias y a partir de sus respectivos intereses, durante la Séptima Convención de Obreros y Campesinos de Durango, celebrada en la ciudad de Gómez Palacio del 1 al 3 de abril de 1927, se produjo la unificación formal de las dos principales organizaciones sociales existentes en la entidad. ${ }^{19}$

Como se apuntaba en párrafos anteriores, los comunistas duranguenses también habían logrado constituir su propia organización política a nivel estatal. En 1926 determinaron reagruparse regionalmente en un nuevo partido: el Partido Durangueño del Trabajo (PDT), filial del Partido Comunista de México. La fundación del partido se llevó a cabo en el poblado de Calixto Contreras del municipio de Peñón Blanco, lugar enclavado en la región de los Llanos y en donde justamente había surgido uno de los primeros núcleos de campesinos organizados por los comunistas. La nueva organización política adoptó como lema partidario: iTierra, Trabajo y Libertad! y determinó que la estructura básica para la organización de sus militantes en la entidad sería a

la Confederación mantenía una estrecha relación y una gran coincidencia social y política.

${ }^{19}$ Acta de la Séptima Convención de Obreros y Campesinos del Estado de Durango. Go mez Palacio, Dgo., 3 de abril de 1927, AGN, fondo Obregón-Calles, exp. 205-G-54. En realidad, el acuerdo de unidad orgánica quedó en simple acto declarativo y no llegó a concretarse. El celo del constituyente hacia la creciente influencia de los "confederados" y sus discrepancias con la radicalización de su lucha agraria, así como los graves conflictos políticos que más adelante lo enfrentarían a los "rojos", impidieron la fusión real de dichas agrupaciones. En la práctica, cada organización mantuvo su propia autonomía y su propia dirigencia. través de la integración de los llamados "clubes" políticos y agraristas. ${ }^{20}$

Al año siguiente de su fundación, la dirigencia estatal del partido, integrada por José Guadalupe Rodríguez, secretario general; Salvador Garay, secretario del interior; Fortino H. Aragón, secretario del exterior; Sixto Fernández, secretario de propaganda, y Santos Marrero, secretario tesorero, estableció su sede en la ciudad de Durango a la vez que dio inicio a la publicación de su propio periódico quincenal: Tierra $y$ Libertad, que complementó la actividad propagandística y organizativa que los rojos venían realizando a través del periódico El Machete, órgano informativo del comité central del PC, el cual era ampliamente conocido y circulaba entre numerosos grupos de agraristas, ferrocarrileros y jornaleros.

Por cierto, la creciente distribución de la prensa comunista y la divulgación de las ideas socialistas entre las masas campesinas, eran cuestiones de gran preocupación y objeto de denuncia por parte de los terratenientes ante el gobierno de la entidad. Al respecto un integrante de la vieja oligarquía latifundista de Durango denunciaba alarmado:

Hace tiempo que en el municipio de El Rodeo está llevándose a cabo una intensa propaganda comunista del todo disolvente y antipatriótica. Tenía yo pleno conocimiento de ella y aunque consciente del peligro que entraña para nuestro país, no había dado ningún

${ }^{20}$ Acta de la Asamblea del Partido Durangueño del Trabajo. Durango, 2 de mayo de 1927, AGN, fondo Dirección General de Gobierno, serie Partidos políticos, vol. 4, exp. 2.312(7)-15. 
paso para hacerla saber a las autoridades superiores $[\ldots]$. En todo el municipio de El Rodeo no se recibe más periódico que $\mathrm{El}$ Machete, libelo comunista que se edita en la capital de la república. Dicho libelo lo reciben los presidentes de los Comités Ejecutivos Particulares Agrarios de la región y sé que le dan lectura en sus juntas, se prestan los ejemplares respectivos, que circulan de mano en mano. Por esto en boca de las mismas autoridades no es raro escuchar las palabras de "Internacional Comunista, Guardias Rojas y Guardias Blancas" [...]. Los campesinos son víctimas de ideas comunistas mal asimiladas y por eso no respetan al gobierno $[. .$.$] , ni las propiedades, ni nada$ y hablan de destrucción de todo lo que tenga algo que ver con el capital $[\ldots]$. Inútil es decir que todos los que somos propietarios de algo estamos expuestos a todas las vejaciones en intereses y personas. Y los comunistas de El Rodeo, que despectivamente llaman Guardias Blancas a los que poseen cualquier cosa o la defienden, hacen propaganda de sus ideas en otros poblados, con grave daño de las instituciones del país y con peligro para la paz pública. ${ }^{21}$

Desde el mismo año de su fundación en 1926, el Partido Durangueño del Trabajo inició también su participación en las contiendas electorales de carácter local, postulanado candidatos en varios ayuntamientos de la entidad, así como al Congreso local. Dos años después, cerca de una docena de sus militantes ocupaban regidurías en diversos cabildos de la región de los Lla-

${ }^{21}$ José M. Fierro al gobernador de Durango. Rodeo, Dgo., mayo de 1929, AGN, fondo Obregón-Calles, exp. 4/565. nos y el PDT contaba entre sus filas con un representante en el Congreso local, el diputado Santos Marrero.

Al mismo tiempo (1926), los dirigentes del PDT habían logrado conformar una alianza opositora al lado de otros partidos políticos locales con el objeto de contender electoralmente en forma conjunta y disputarle la primacía política al denominado Partido Revolucionario Durangueño, al cual catalogaban como el "partido oficial", ya que mantenía el control y el monopolio político en la entidad y era acaudillado por el gobernador del estado, el general Enrique C. Nájera y, como es de suponer, disfrutaba del respaldo político y los recursos económicos que la administración gubernamental le concedía para su acción proselitista. $^{22}$ Además, tanto el citado gobernador -integrante de la facción carrancista de los hermanos Arrieta durante la revolución-, como su partido, eran catalogados por los rojos adversarios de la lucha de los campesinos y del reparto agrario. El frente electoral opositor organizado fundamentalmente por iniciativa de los comunistas se denominó Alianza de Partidos por el

${ }^{22}$ El Partido Revolucionario Durangueño había sido el partido triunfador en las elecciones locales y federales de 1924 y 1926 y a través del cual arribó a la gubernatura el general Nájera en 1924. Desde entonces sus integrantes detentaban la mayoría en los ayuntamientos, así como en el Congreso local. Al frente de la directiva del partido se encontraba el ex diputado constituyente Antonio Gutiérrez, fiel aliado del gobernador Nájera. Véase Programa Político y de Acción del Partido Revolucionario Durangueño. Durango, 13 de mayo de 1926, AGN, fondo Dirección General de Gobierno, serie Partidos políticos, vol. 4, exp. 2.312(7)-13. 
Bien de Durango, y fue integrada con la participación del Partido Socialista del Estado de Durango (PSED), el Partido Revolucionario Ferrocarrilero de Durango (PRFD) y el Partido Durangueno del Trabajo (PDT).

El Partido Socialista del Estado de Durango también había surgido formalmente en el año de 1926, empero, era sucedáneo y heredero del Partido Agrarista Durangueño fundado en 1920. Desde entonces era dirigido por el grupo político que encabezaban Terrones Benítez y el revolucionario duranguense Jesús Agustín Castro, gobernador de la entidad durante el periodo 1920-1924. La base social de esta organización política estaba integrada mayoritariamente por los grupos y comités adheridos al Sindicato de Campesinos Agraristas que presidía el ex constituyente. Al frente de los otros dos partidos participantes en la Alianza: el Revolucionario Ferrocarrilero y el Durangueño del Trabajo, como ya hemos dicho, estaban los militantes comunistas.

\section{LA REELECCIÓN OBREGONISTA Y SUS SECUELAS POLÍTICAS EN DURANGo}

A principios del año de 1928 los distintos partidos y fuerzas políticas duranguenses, entre ellos la Alianza de Partidos por el Bien de Durango, se aprestaban para participar en las elecciones locales y federales que se celebrarían en el verano de ese año. A través de las elecciones del mes de junio habría de elegirse al nuevo gobernador para el periodo 1928-1932 y renovarse la legislatura local, en tanto que los comicios federales de julio comprenderían la elección presidencial y la designación de los representantes de la entidad ante el Congreso de la Unión.

Para entonces el proyecto reeleccionista del general Álvaro Obregón era un hecho indiscutido. Su marcha hacia Palacio Nacional aparentemente había quedado libre de obstáculos tras vencer las resistencias políticas que habían surgido dentro de las propias "filas revolucionarias", ordenar la eliminación de aquellos que intentaron oponerse a su reelección y haber conseguido, mediante la acción de sus incondicionales, que en el Congreso de la Unión se derogaran los artículos de la Constitución que se interponían en su camino para alcanzar de nueva cuenta la primera magistratura del país.

En Durango, al igual que en el resto del país, la mayoría de las organizaciones partidarias habían determinado adherirse a la candidatura presidencial del caudillo sonorense. Esta postura también era compartida por los partidos locales dirigidos por los comunistas duranguenses, respondiendo así a la directriz política adoptada nacionalmente por el comité central del Partido Comunista de sumarse a la campaña del general Obregón y postularlo como su candidato presidencial.

Sin embargo y pese a la adhesión brindada por los distintos partidos y grupos políticos duranguenses a la candidatura del general Obregón, los planes políticos del caudillo en relación con la sucesión gubernamental que se avecinaba en Durango no eran concordantes con los de aquéllos. Desestimando los pronunciamientos hechos por los diversos partidos locales en 


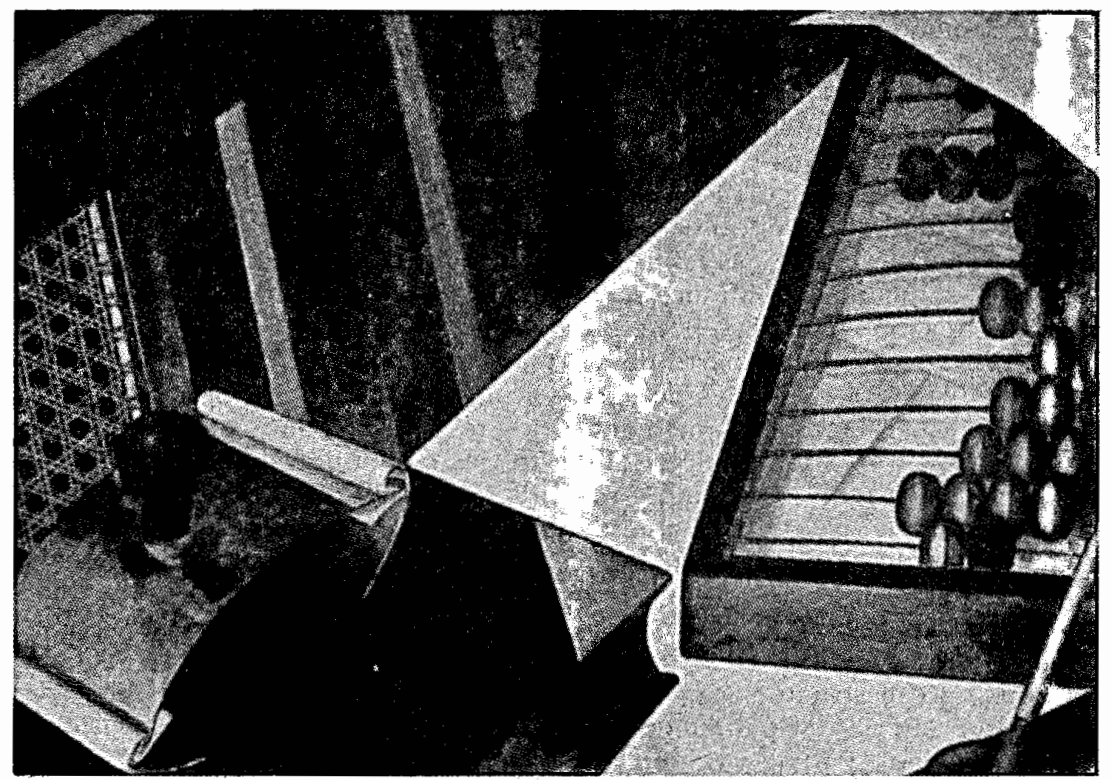

favor de la nominación de algunos de los personajes políticos de la entidad para contender por la gubernatura, el caudillo sonorense determinó promover y respaldar otra candidatura: la del general Juan Gualberto Amaya, un hombre plenamente identificado con su facción.

La designación del general Amaya como candidato oficial del obregonismo representó un duro golpe para la "familia revolucionaria" duranguense, ya que vulneraba su derecho a decidir y resolver sobre los asuntos políticos de la entidad y fue percibido como un acto de intromisión e imposición del caudillo, a la vez que argumentaban que el general Amaya era un candidato sin arraigo y carente de trayectoria política en el estado. Efectivamente, las impugnaciones al candidato obregonista no eran simples falacias o invenciones de quienes se oponían a su nominación. En realidad, la carrera política y militar del general Amaya -quien era oriundo de Durango- había transcurrido lejana a la vida política de la entidad, en otros sitios del país y por lo general bajo el mando y protección del hombre de Huatabampo. ${ }^{23}$

${ }^{23}$ Juan Gualberto Amaya nació en Santa María del Oro, Durango. Se incorporó a las filas del Ejército Constitucionalista bajo las órdenes de Álvaro Obregón. Adherente del Plan de Agua Prieta, al término de la lucha armada continuó en las filas del ejército federal. Obtuvo el nom- 
No obstante el rechazo generalizado a la imposición de Amaya por parte de las organizaciones políticas locales, el general Obregón mantuvo la determinación de sostener su candidatura y de guiar sus pasos hasta la gubernatura de la entidad. El refrendo de su patrocinio político hacia el general Amaya quedó de manifiesto durante el recorrido que Obregón realizó por el estado de Durango como parte de su campaña electoral en el mes de abril de 1928, al participar conjuntamente en diversos actos y mítines electorales en varias poblaciones, así como en la capital duranguense, ratificó abiertamente el respaldo hacia su favorito. Sin embargo, al mismo tiempo pudo advertir la escisión que se había producido entre los grupos políticos duranguenses, el escaso entusiasmo de la población ante la campaña electoral de su protegido y los contratiempos que éste tuvo que enfrentar para formalizar su postulación como candidato. Ninguno de los partidos existentes en la entidad había aceptado nominarlo, por lo que Amaya y el reducido grupo de seguidores que apoyaban su candidatura se habían visto en la imperiosa necesidad de constituir en forma urgente su propia organización política. Por supuesto, el registro formal del partido de los "amaya-obregonistas" se resolvió en forma expedita y sin tropiezo alguno, surgiendo así, en unos

bramiento de general de brigada durante la campaña contra el movimiento "delahuertista". Jefe de Operaciones Militares entre 1925 y 1928 en los estados de Coahuila, Puebla y Oaxaca, hasta antes de su nominación como candidato a gobernador no había sido designado para ocupar ningún cargo de elección pública. cuantos días, el partido que postularía al general Amaya a la gubernatura y al general Obregón a la presidencia de la república: el Partido Reconstructor Durangueño. ${ }^{24}$

Ante la determinación política impuesta desde el Olimpo obregonista, la Alianza de Partidos por el Bien de Durango, el Sindicato de Campesinos Agraristas y la Confederación de Sindicatos de Obreros y Campesinos, así como otras organizaciones políticas regionales, resolvieron enfrentar electoralmente la candidatura de Amaya, postulando su propio candidato al gobierno de la entidad; pese a que ello entrañaba un abierto desafio al poder del caudillo, el cual -nadie lo dudaba- alcanzaría otra vez en breve tiempo el mando presidencial. Para hacer efectiva y concretar dicha iniciativa electoral, los partidos "aliancistas" y las organizaciones sociales y políticas coligadas, Llamaron a la celebraciốn de la Convención General de la Alianza de los Partidos por el Bien de Durango que se llevó a efecto el 20 de mayo de 1928 en el Teatro Principal de la capital del estado. Contando con la presencia de centenares de obreros y campesinos pertenecientes a las organizaciones aliadas que se movilizaron desde diversos lugares de la entidad y, según sus convocantes, con una asistencia superior al acto de postulación del "candidato oficial", la Convención acordó nominar como su candidato a gobernador al constituyen-

${ }^{24}$ Solicitud de registro del Partido Reconstructor Durangueño ante la Secretaría de Gobernación. Durango, 12 de junio de 1928, AGN, fondo Dirección General de Gobierno, serie Partidos políticos, vol. 4, exp. 2.312(7)*21. 
te Alberto Terrones Benítez. ${ }^{25}$ Además de esta nominación, la Convención designó candidatos a la legislatura local y al Congreso de la Unión entre los integrantes de los partidos que conformaban la Alianza. Por los comunistas del Partido Durangueño del Trabajo fueron designados Fortino $\mathrm{H}$. Aragón y J. Guadalupe Rodríguez para contender a diputados federales.

Los partidos convencionistas acordaron, asimismo, enarbolar la candidatura presidencial del general Álvaro Obregón, señalando que lo hacían en razón del apoyo que el sonorense había otorgado a los campesinos duranguenses para la restitución de tierras y la fundación de ejidos durante su ejercicio al frente del ejecutivo nacional, así como por sus múltiples méritos revolucionarios. Es probable que mediante el pronunciamiento en favor de Obregón, además, los partidos coligados buscaran evitar o atemperar el conflicto con el caudillo. Entendían, sin duda, que al rechazar y luchar en contra de la candidatura de Amaya se habían insubordinado a sus designios.

En cuanto se puso en marcha la campaña electoral de los Partidos de la Alianza, el grupo obregonista comandado por Amaya se dio a la tarea de denunciar públicamente, así como ante el Centro Director Obregonista y el propio caudillo, que la postulación de Terrones Benítez y la lucha electoral emprendida por dichos partidos no eran sino el resultado de una confabulación orquestada entre el gobernador Enrique C. Nájera, la legislatura local

${ }^{25}$ Terrones, Anecdotario, 1986, pp. 18-19. y los partidos "aliancistas", cuyo objetivo de fondo era socavar la campaña presidencial de Obregón en la entidad. Sostenían que el gobernador, en forma velada, apoyaba políticamente y financiaba con recursos del erario público la actividad del grupo opositor. Un argumento más que utilizaron para acreditar la supuesta conjura "antiobregonista", fue el recordatorio de la postura sostenida por el licenciado Alberto Terrones Benítez y el general Jesús Agustín Castro cuando ambos eran senadores por Durango y formaban parte del Bloque Antirreeleccionista que se opuso a las reformas que abrieron el camino a la reelección. Como hemos señalado, éstos eran los principales dirigentes del Partido Socialista de Durango, integrante de la Alianza, y el ex diputado constituyente Terrones, su candidato a gobernador. Sin embargo, las principales baterías de Amaya y su grupo estaban dirigidas en contra del "grupo de agitadores" del Partido Durangueño del Trabajo; con gran irritación delataban "la labor de desorientación y engaño" que éste desarrollaba entre los obreros y campesinos de la entidad. Simultáneamente, en forma secreta, pidieron al caudillo intervenir "a la mayor brevedad posible" para atajar la campaña electoral de sus adversarios. ${ }^{26}$

Mucho antes de lo esperado, el Macbeth de Huatabampo empezó a mover los hilos de la política duranguense

${ }^{26}$ General Juan Gualberto Amaya al Centro Director Obregonista. Durango, 21 de mayo de 1928, AGN, fondo Dirección General de Gobierno, serie Elecciones para gobernador, vol. 227, exp. $2.311 \mathrm{G}(7)-1$. 
con la mano que aún le quedaba. Apenas cinco días después de realizada la Convención, los partidos de la Alianza recibieron la primera señal de advertencia de Obregón, mediante la cual dejaba en claro que no estaba dispuesto a ceder en su empeño de imponer en el gobierno local a su aliado y seguidor, el general Amaya. Así, "por órdenes superiores" -nunca se precisó por parte de quién o quiénes-, se hizo presente en la capital duranguense, al mando de un destacamento militar, el general de división Gonzalo Escobar, jefe de Operaciones Militares en la región lagunera. Tras celebrar una breve y urgente reunión con el general Francisco Urbalejo, jefe de Operaciones Militares en Durango, el general Escobar asumió el control militar de la entidad. A continuación, sostuvo una entrevista con el gobernador Enrique C. Nájera y al finalizar ésta, en la media noche del 26 de mayo de 1928, el gobernador anunció su renuncia, advirtiendo que su decisión era totalmente "voluntaria" y sin que hubiese existido presión o emplazamiento alguno por parte del general Escobar. Luego, previo acuerdo entre éste y nueve de los quince diputados -es decir, la fracción "amayaobregonista"-, el Congreso local acep. tó sin mayor trámite la renuncia de Enrique C. Nájera. Por mera coincidencia el nombramiento de gobernador substituto recayó en el diputado Jose C. Aguirre, representante por Santa María del Oro, paisano y compadre del general Amaya.

Los partidos de la Alianza y las organizaciones obreras y agrarias que respaldaban la campaña electoral opositora, aseveraron sin tardanza que la salida de Nájera constituía en realidad "un cuartelazo militar" y que la artera e ilegal intervención del general Escobar representaba una flagrante violación a la soberanía de la entidad. Advertían que mediante esa burda maniobra los seguidores de Amaya pretendían disponer de todos los engranajes electorales para impedir el triunfo del pueblo duranguense en las próximas elecciones, y que los amayistas habían tenido que recurrir a tal patraña debido al inexistente respaldo popular hacia su candidato y para frenar la "arrolladora" campaña de los obreros y campesinos al lado de los candidatos de la "Alianza". A la vez, calificaban de ilegal el nombramiento del gobernador sustituto aprobado por el Congreso. Concluían que al haberse violentado la soberanía y la Constitución de la entidad por parte de los mandos militares y la propia legislatura local, habían dejado de existir los poderes políticos en el estado. ${ }^{27}$

Como es de suponer, Amaya y sus partidarios rechazaron las acusaciones vertidas por los partidos de la Alianza y negaron tajantemente que el "pundonoroso" general Escobar hubiese intervenido para destituir al gobernador Enrique Nájera. Afirmaban que tales infundios no eran sino producto de las malévolas y bastardas ambiciones de Terrones Benítez y del grupo de "agitadores" que lo rodeaban. ${ }^{28}$ Por su parte, el gobierno federal, ante estos sucesos

\footnotetext{
${ }^{27}$ Manifiesto al pueblo de Durango. Alianza de Partidos por el Bien de Durango. Durango, 31 de mayo de 1928 , en ibid.

${ }^{28}$ Partido Reconstructor Durangueño al pue. blo de Durango. Durango, 28 de mayo de 1928, en ibid.
} 


\section{SECUENCIA}

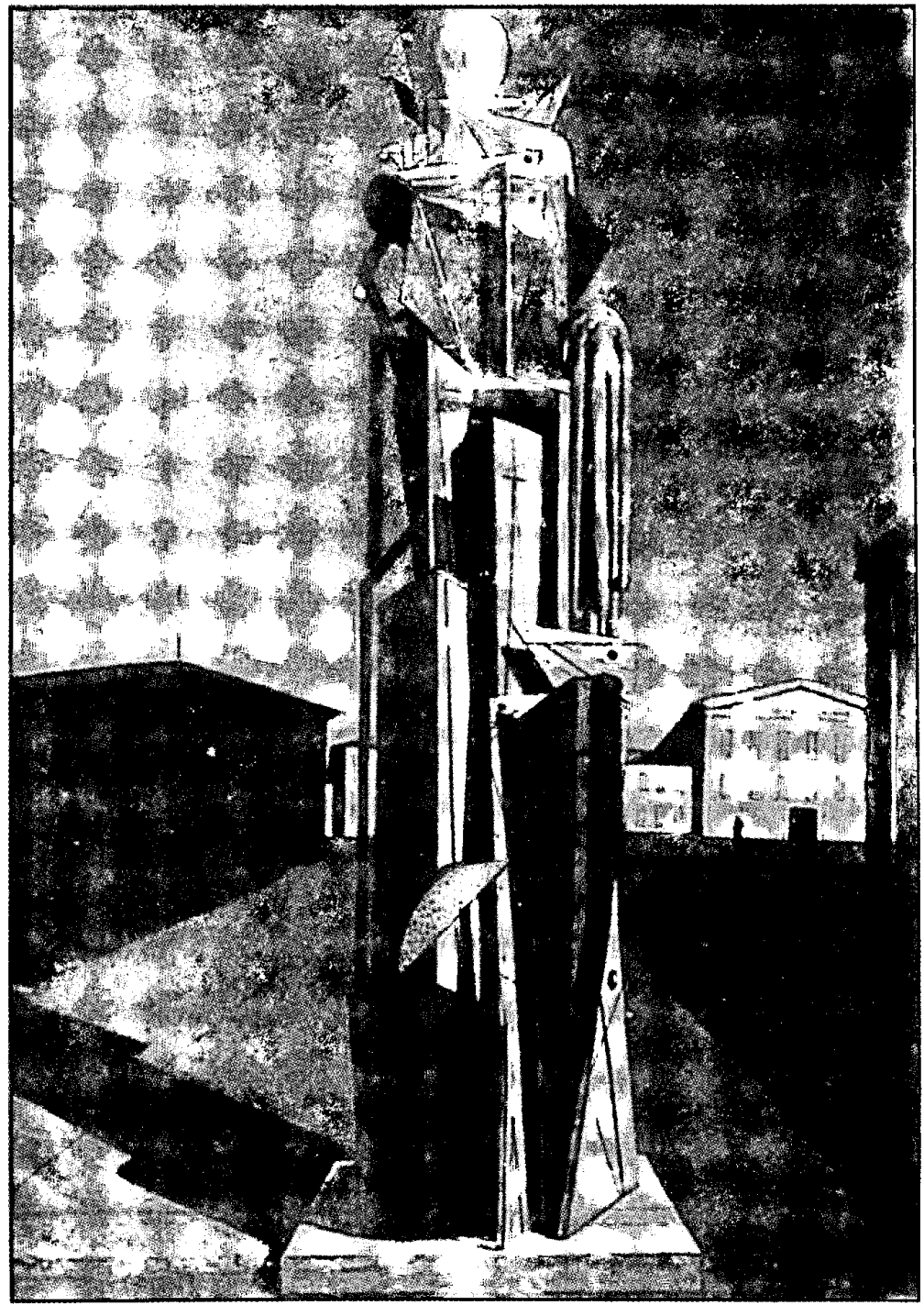


políticos, y pese a la denuncia y solicitud que los partidos de la Alianza hicieron para que interviniera en la solución del conflicto, optó por la complicidad del silencio. Mientras tanto y al cobijo de las situación que se presentaba en la entidad, las bandas cristeras que se mantenían levantadas en armas arreciaron el hostigamiento y los ataques en contra de los ejidos y los poblados agraristas, especialmente hacia aquellos vinculados a la confederación "roja" y al Partido Durangueño del Trabajo. Tan sólo en el municipio de la capital, durante el mes de mayo, los alzados en nombre de Cristo Rey ejecutaron a once agraristas y dejaron decenas de heridos. ${ }^{29}$

Todas estas circunstancias y conflictos políticos condujeron a los partidos integrantes de la Alianza a señalar que no existían las condiciones políticas ni las mínimas garantías jurídicas para continuar en la campaña para la renovación de gobernador y de Congreso local. Aducían que habían desaparecido los poderes políticos y que la entidad se encontraba bajo control militar. A través de un manifiesto publicado el 31 de mayo de 1928 informaban su determinación de retirarse de la contienda y seguir luchando para detener el viciado proceso electoral y lograr el restablecimiento del régimen constitucional en el estado. ${ }^{30}$

\footnotetext{
${ }^{29}$ Los campesinos agraristas ejecutados por los cristeros pertenecían al poblado de Durazno del municipio de la capital. Véase A mis amigos, correligionarios y compañero de lucha. Alberto Terrones Benítez, en $i b i d$.

${ }^{30}$ Manifiesto al pueblo del estado. Comité Ejecutivo de la Alianza de Partidos por el Bien
}

Sin embargo, de nada sirvieron los cuestionamientos y el retiro de la Alianza para detener el proceso electoral. Las elecciones se llevaron a cabo en la fecha programada (10 de junio de 1928). Con la declinación de Terrones Benítez y los demás candidatos de la Alianza, el general Amaya y sus correligionarios prácticamente quedaron sin adversarios. ${ }^{31}$ Sólo tuvieron que contender con la débil y casi inexistente candidatura del coronel Juan B. Fuentes, quien a última hora fue nominado a la gubernatura por el Partido Liberal Nacionalista, organización que agrupaba al pequeño reducto de seguidores del antiguo carrancista Domingo Arrieta. Como era de esperarse, el partido de Amaya obtuvo un triunfo arrasador. Al contabilizarse los votos para gobernador, al candidato del obregonismo se le asignaron más de $35^{\circ} 000$ votos, en tanto que a su "contendiente" le fueron reconocidos sólo 800; igualmente se anunció que todos los candidatos a diputados del Partido Reconstructor habían "triunfado en forma amplia e inobjetable".

Tras la celebración de los comicios locales, los partidos de la Alianza emprendieron la lucha por su nulificación. A través de múltiples actas de protesta, proclamas y manifiestos, demandaron al ejecutivo federal para que mediara en la emisión de una nueva convocato-

de Durango. Durango, 31 de mayo de 1928, en ibid.

${ }^{31}$ La expulsión de Enrique Nájera de la gubernatura trajo consigo el derrumbe y desaparición del Partido Revolucionario Durangueño. Por ende, dicho partido ya no participó en los comicios locales y federales celebrados en el verano de 1928. 
ria para la realización de nuevas elecciones. En uno de los documentos que hícieron llegar al presidente Plutarco Elías Calles y en el que se sintetizaban las demandas de la Alianza, le pedían declarar desaparecidos los poderes en la entidad, designar un gobernador provisional y convocar de nueva cuenta a elecciones, ya que sólo de esa manera "el pueblo de Durango podría ejercer el sufragio efectivo y, únicamente entonces, obtendría la justicia que hoy reclama" ${ }^{32}$ Expresaban que dicho clamor contaba con el respaldo de los 60000 campesinos y obreros integrantes de las organizaciones y partidos de la Alianza. Sin embargo, tampoco volvieron a obtener respuesta alguna del general Calles. Además, la campaña emprendida por la Alianza para nulificar los resultados electorales empezó a evidenciar señales de fractura: el diputado local del Partido Durangueño del Trabajo, Santos Marrero, defeccionó de las filas comunistas para unirse al bando del general Amaya, y el candidato a gobernador postulado por la Alianza, el licenciado Terrones Benítez, dejó "colgados de la brocha" a sus partidarios al abandonar la entidad. ${ }^{33}$

${ }^{32}$ Alianza de Partidos por el Bien de Durango. Al pueblo del estado. Durango, 15 de agosto de 1928, AGN, fondo Dirección General de Gobierno, serie Elecciones para gobernador, vol. 227, exp. 2.311G(7)-1.

${ }^{33}$ El propio Terrones Benítez explicó con posterioridad el motivo de su abandono de la lucha electoral: el jefe del Estado Mayor del presidente Calles, por via telefónica y por instrucciones del propio presidente, le pidió alejarse de la contienda política y salir del estado de Durango, a lo cual accedió el constituyente. Sin embargo, años más adelante, Terrones Benítez inventó una nueva versión: que había sido
Por ende, la responsabilidad de seguir luchando en contra de Amaya y correr Ios riesgos que entrañaba seguir enfrentando a las triunfantes huestes del obregonismo, tuvo que ser asumida por los comunistas y las organizaciones obreras y agrarias que éstos dirigían.

Tres semanas después de la celebración de las elecciones locales y sin cambio alguno en la situación política que privaba en la entidad, se efectuaron las elecciones federales ( 1 de julio de 1928), en las que resultaron nuevamente triunfantes en forma contundente todos los candidatos a senadores y diputados federales postulados por el Partido Reconstructor. Por cierto, entre los representantes electos destacaban el otrora revolucionario Pastor Rouaix, convertido ya para entonces en adicto seguidor del grupo sonorense, así como el protegido de Obregón y compadre del general Amaya: Jesús Salas Barraza, autor material del asesinato del general Francisco Villa. En cuanto a la elección presidencial, la maquinaria electoral manejada por Amaya y los reeleccionistas también operó eficientemente; según sus cuentas, el general Obregón obtuvo más de 40000 votos en la entidad.

Aun cuando las movilizaciones y protestas de los Partidos de la Alianza se

secuestrado por dicho jefe militar y conducido a Zitácuaro y luego a la ciudad de México en donde fue puesto en libertad a condición de abstenerse de retornar a Durango y de seguir participando en los asuntos políticos de la entidad. No existen evidencias que corroboren esta última versión. De acuerdo con lo expresado por sus aliados y correligionarios de la Alianza, simplemente se ausentó de Durango, seguramente tras haber pactado con el mensajero del general Calles. 
intensificaron en las semanas siguientes con el propósito de evidenciar ante el gobierno federal el rechazo existente en la entidad hacia el general Amaya e impedir que éste asumiera la gubernatura, la silente actitud del gobierno central no se modificó. Además, el inesperado asesinato del general Obregón vino a precipitar el desenlace del conflicto político-electoral que se vivía en Durango. Ante la incierta y compleja situación política en la que de pronto se sumergió el país, Amaya y sus seguidores resolvieron actuar con celeridad para evitar que se les fueran de las manos las posiciones políticas que habían alcanzado al amparo y protección del caudillo. Cerca de la media noche del mismo día que Obregón fue ejecutado, el Congreso local -integrado mayoritariamente por "amayistas"se apresuró a declarar gobernador electo a Juan Gualberto Amaya para el cuatrienio 1928-1932..$^{34}$

Como es sabido, a raíz del asesinato del general Obregón se produjo la más profunda crisis política de cuantas había tenido que enfrentar hasta entonces el régimen posrevolucionario. La coyuntura política se tornó compleja y riesgosa para el propio presidente Calles. Los obregonistas se aglutinaron amenazadoramente no sólo para exigir la aclaración del asesinato del caudillo, sino también para reivindicar su derecho y legitimidad para asumir la conducción del país. Ante la influencia política y la fuerza de que

${ }^{34}$ De los diputados secretarios de la legislatura de Durango al presidente Plutarco Elías Calles. Durango, 18 de julio de 1999, AGN, fondo Obregón-Calles, exp. 202-D-5. disponían dentro del ejército, Calles debió obrar conciliatoriamente y con mesura. Por un lado, para asumirse como el garante de la legalidad constitucional ante todas las facciones políticas de la "familia revolucionaria" y, por otro, para evitar que se desbordaran las ambiciones en pugna y derivaran en estallidos o sublevaciones con motivo de la sucesión presidencial. Por ende, la posibilidad de que Calles hubiese intervenido en el conflicto duranguense en los términos que deman. daban los Partidos de la Alianza, se tornó todavía más inviable tras la muerte de Obregón. En medio de tales circunstancias, impedir que Amaya ocupara el gobierno de Durango hubiese sido interpretado por la "banda" obregonista como un desafio político de Calles. La conjunción de todos estos factores y condicionantes políticas fueron determinantes para frustrar los empenos del movimiento social y político conformado por las organizaciones radicales duranguenses, cuyo núcleo impulsor lo constituían los líderes agrarios y dirigentes políticos de filiación comunista.

De esta manera, y a la vuelta de unos cuantós días, el general Amaya tomó posesión como gobernador constitucional del estado. Las notas de los corresponsales de $\boldsymbol{E l}$ Machete en Durango reseñan el elegante y fastuoso baile con el que Amaya fue agasajado la noche del 15 de septiembre por la elite duranguense: hacendados, banqueros, comerciantes, Caballeros de Colón y lo más granado de la "familia revolucionaria". Asimismo, informan acerca del estado de plácemes y alegría en el que se encontraban los te- 
rratenientes y los grupos tradicionalmente conservadores de la "Perla del Guadiana" con el nuevo gobernante, el cual se había comprometido a poner fin a la acción subversiva y disolvente de los "agitadores" agraristas y líderes comunistas. A decir de ellos, se aprestaban para iniciar una renovada etapa de "tranquilidad, paz y progreso". ${ }^{35}$ En tanto, apuntaban, los trabajadores, campesinos agraristas y los más pobres, se organizaban para resistir la embestida que preparaban el gobierno y la oligarquía duranguense.

En efecto, el perfil autoritario y conservador del gobierno encabezado por el general Amaya muy pronto quedó de manifiesto. La elite económica y los grandes terratenientes de la vieja oligarquía porfiriana se alzaron como sus principales aliados. Su red de alianzas incluyó además a las agrupaciones de corte clerical y reconocidamente reaccionarias como la de los Caballeros de Colón, a cuyos miembros "obsequió" el Ayuntamiento de la capital mediante su decidido apoyo en las elecciones de diciembre de 1928 , y a quienes se achacaba que encubrían y financiaban a los cristeros levantados en armas, según denunciaron entonces diversos grupos políticos de la entidad. ${ }^{36}$

${ }^{35}$ El Machete, 24 de septiembre de 1928 , México.

${ }^{36}$ Denuncia del Partido Ferrocarrilero Unitario ante la Secretaría de Gobernación. México, D. F., 20 de diciembre de 1928; Liga Nacional Campesina al ministro de Gobernación, México, 21 de diciembre de 1928, AGN, fondo Dirección General de Gobierno, serie Agrupaciones sindicales, vol. 22-A, exp. 2.331.8(7)-52. Entre los individuos que se señalaban como miembros de los Caballeros de Colón e integrantes del Ayuntamiento de Durango se mencionaba al doctor
En contrapartida, Amaya y su grupo se empeñaron en desmantelar la influencia social y política de sus opositores, particularmente encarrilaron la confrontación hacia la corriente liderada por Terrones Benítez y las organizaciones agrarias, sindicales y partidarias encabezadas por Guadalupe Rodríguez y el núcleo de dirigentes comunistas. De esta manera se inició una sistemática persecución en contra de los grupos agraristas y campesinos solicitantes de tierra organizados por los "agitadores bolshevikis". Varios núcleos campesinos fueron despojados de las tierras que venían ocupando y que mantenían en disputa con terratenientes y hacendados. En tanto que algunos dirigentes campesinos de la Confederación Roja fueron encarcelados bajo el cargo de supuestos delitos del orden común, siempre en perjuicio de hacendados y terratenientes: abigeato, despojo, asalto y robo.

Así, en diciembre de 1928 fueron llevados a prisión Fortino H. Aragón, secretario general de la Confederación; Francisco Ávila, presidente de la Liga Pro-Luchadores Perseguidos; Lorenzo Gutiérrez, administrador de El Debate, órgano periodístico de la Confederación, y Sixto Fernández, secretario de prensa y propaganda del Partido Durangueño del Trabajo. ${ }^{37}$

Carlos León de la Peña, al ingeniero Julio Guerrero y a José A. Martínez.

${ }^{37}$ Denuncia de la Liga Nacional Campesina al presidente Emilio Portes Gil. México, D. F., 21 de diciembre de 1928, en AGN, Dirección General de Gobierno, serie Elecciones presidente municipal, vol. 387, exp. 2.311M(7)-19 y; Sindicato Mártires de Chicago al Congreso Local del Estado de Durango. Guadalupe Victoria, 
Igualmente, el gobierno y la Jefatura de Operaciones Militares, a cuyo mando seguía el general Urbalejo, em. prendieron el desarme de ejidatarios y grupos agraristas que el gobierno había pertrechado desde el año de 1926 para enfrentar la revuelta cristera. Ello significó, según advirtieron los dirigentes del Partido Durangueño del Trabajo, dejar inermes a los campesinos ante las incursiones de las bandas cristeras, pero también frente a los ataques perpetrados por las gavillas de "guardias blancas" organizadas por los latifundistas, las cuales habían redoblado las hostilidades hacia el movimiento agrarista a partir de su desarme. Además, ante la supuesta negativa de algunos núcleos campesinos para entregar las armas, el ejército ejecutó a varios líderes agraristas pertenecientes a la Confederación de Sindicatos Obreros y Campesinos, entre ellos a Fortino Soto, Cirilo Pánuco y Manuel Soto, del Comité Agrario de Esperanza, del municipio de Peñón Blanco, que fueron colgados por una partida de federales. En torno a este caso, los dirigentes de la Confederación denunciaron que los campesinos de Esperanza en realidad fueron asesinados a petición y en complicidad con los hacendados a los que afectaban con su solicitud de dotación de tierras y no por su resistencia a desarmarse. ${ }^{38}$

En tanto, en el plano de la política nacional, el general Amaya y sus correligionarios en el gobierno duranguense se habían embarcado en la confor-

Dgo., 24 de diciembre de 1928, en ibid., exp. $2.311 \mathrm{M}(7)-18$.

${ }^{38}$ El Machete, 23 de enero de 1929. mación de la facción obregonista que se conjuntó luego de la muerte del caudillo y que rechazó someterse al liderazgo de Calles, así como a las nuevas reglas políticas que éste pretendía im. poner al conjunto de la "familia revolucionaria". La disidencia obregonista, integrada por un gran número de los altos mandos del ejército y un importante bloque de políticos civiles, llegó a la conclusión que Calles -luego de la designación de Emilio Portes Gil como presidente interino y del llamado para integrar la nueva formación partidaria- había decidido privarlos de las posiciones políticas que les correspondían y excluirlos del proceso mediante el cual se nominaría al candidato presidencial para las elecciones extraordinarias del año 1929. A partir de esta postura política se fue gestando el alzamiento de los militares obregonistas. Entre los principales conspiradores destacaban los generales Francisco R. Manzo, Jesús M. Aguirre, Gonzalo Escobar, Fernando Zertuche y Francisco Urbalejo, jefes de Operaciones Militares de Sonora, Veracruz, La Laguna, Estado de México y Durango, respectivamente, así como los gobernadores y también generales Fausto Topete de Sonora y Juan Gualberto Amaya de Durango.

Mientras se afinaban los planes para la insurrección, la facción obregonista intentó encubrir sus verdaderos propósitos mediante la postulación del licenciado Gilberto Valenzuela como candidato a la presidencia de la república. En función de tal estrategia, el gobernador Amaya, así como los diputados federales y locales duranguenses, hicieron pública su adhesión a la can- 
didatura de Valenzuela en diciembre de 1928, a la vez que se dieron a la tarea de organizar un frente electoral, encabezado por el Partido Reconstructor Durangueño y otros partidos locales, al que denominaron Confederación de Partidos Obregonistas del Estado de Durango Pro-Valenzuela ${ }^{39}$ Sin embargo, la ruta que los obregonistas se habían trazado tenía como primera estación la sublevación militar puesta en marcha. Por ello, no fue casual que al mismo tiempo que en la ciudad de Querétaro emergía el Partido Nacional Revolucionario, estallaba la revuelta militar acaudillada por el general Gonzalo Escobar (3 de marzo de 1929), bajo las consignas emanadas del llamado Plan de Hermosillo. ${ }^{40}$

La excitativa golpista fue secundada inmediatamente por el gobernador, el Congreso local, los diputados federales y la mayoría de los ayuntamientos de la entidad, así como por la Jefatura de Operaciones Militares de Durango que, de facto, desconocieron a los poderes de la federación. Los generales Urbalejo y Amaya asumieron el mando de las fuerzas militares insurrectas, integradas por cerca de 2000 efectivos, aprestándose para repeler la campaña militar que el gobierno federal emprendió para sofocar la asonada escobarista. Dado que sus tareas como estratega militar le impedían seguir al frente de la gubernatura, Amaya soli-

${ }^{39}$ Consejo Directivo de la Confederación de Partidos Obregonistas del Estado de Durango Pro-Valenzuela al secretario de Gobernación. Durango, 21 de enero de 1929, AGN, fondo Dirección General de Gobierno, serie Partidos políticos, vol. 4, exp. 2.312(7)-23.

${ }^{40}$ Loyola Díaz, Crisis, 1987, p. 143. citó licencia temporal para separarse del cargo en tanto la insurrección se alzaba triunfante. A propuesta suya, el "honorable Congreso" duranguense designó como gobernador sustituto, al no menos "honorable" diputado federal, Jesús Salas Barraza ( 5 de marzo de 1929).

La lucha de los insurrectos en territorio duranguense muy pronto devino en un rotundo fracaso. A los primeros embates, la asonada fue desarticulada por las fuerzas militares enviadas por el gobierno federal. ${ }^{41}$ Ello indujo a los generales Amaya y Urbalejo a pactar una alianza con los jefes de las bandas cristeras para combatir en forma mancomunada a las tropas federales, a cambio de dotarlos de dinero y armamento. Además, los militares insurrectos tuvieron que enfrentar en su propia retaguardia a los destacamentos armados organizados por los campesinos agraristas de la Confederación de Sindicatos Obreros y Campesinos de Durango y del Partido Durangueño del Trabajo que, al llamado del Partido Comunista y del gobierno federal, se sumaron para aplastar la revuelta. ${ }^{42}$

En muy poco tiempo las fuerzas insurrectas fueron expulsadas de la entidad por las tropas federales y los destacamentos agraristas $\mathrm{y}$, semanas más tarde, en el territorio de Chihuahua se produciría la derrota final de la asonada escobarista. Sin embargo, quedaba aún por resolver la guerra cristera que azotaba a la entidad, la cual había

${ }^{41}$ En cuanto a los hechos de guerra de la revuelta escobarista, véase Meyer, Historia, 1978, vol. 12, pp. 64-84.

${ }^{42}$ Amaya, Gobiernos, 1947, pp. 257-258. 
repuntado al amparo de los acontecimientos políticos de los meses anteriores y al apoyo que Amaya y sus aliados le concedieron. Como era previsible, el Congreso de la Unión declaró desaparecidos los poderes políticos en el estado de Durango. Por su parte, el general Amaya, Urbalejo, Salas Barraza, la mayoría de los integrantes del Ayuntamiento de la capital y de la diputación federal, así como el Congreso local en pleno, tuvieron que huir hacia el exilio político en Estados Unidos. En tanto que, por esas paradojas y vueltas que ofrece la vida política, el presidente Portes Gil, a sugerencia de Plutarco Elías Calles, designó como gobernador provisional al licenciado Alberto Terrones Benítez, justo a quien, unos meses atrás, prácticamente se le había impedido contender por el cargo. Aparentemente, los enfrentamientos sociales y políticos del pasado inmediato empezaban a ser remontados. Empero, otras grietas políticas habían aparecido dentro del tejido social duranguense, $y$ al ahondarse producirían nuevas contradicciones y conflictos.

LA PRIMAVERA SE TIÑE DE ROJO. REPRESIÓN Y DECAPITACIÓN DEL MOVIMIENTO AGRARISTA RADICAL

Con el ascenso de Terrones Benítez al poder ejecutivo estatal, podría suponerse que el movimiento agrarista y las fuerzas políticas que habían actuado conjuntamente dentro de la Alianza de Partidos por el Bien de Durango no sólo mantendrían su unidad de acción, sino que además constituirían el principal soporte político del nuevo gobier- no. A la vez éste daría marcha atrás en la alianza establecida entre la anterior administración y las elites económicas, los hacendados terratenientes y los grupos conservadores de la entidad. Igualmente era de suponer que el nuevo gobierno desarrollaría una política mucho más abierta y receptiva en relación con las demandas agrarias de miles de campesinos solicitantes de tierras y apoyaría la constitución de ejidos, a la par que respetaría y haría valer los reclamos y derechos de los trabajadores. Pero, sobre todo, era de esperar que bajo la gestión del ex diputado constituyente se pondría fin a la política de represión desatada por la administración de Amaya en contra de los luchadores sociales, las organizaciones obreras y agrarias y los partidos políticos opositores.

Ello no ocurrió así. Por el contrario. A consecuencia de la forma en que evolucionaron los acontecimientos políticos a partir del recambio en el gobierno, se desembocó en un nuevo y violento conflicto. Sólo que ahora los actores y adversarios centrales en la confrontación serían las fuerzas políticas que anteriormente habían conformado la Alianza de Partido por el Bien de Durango. Desde el aparato gubernamental, Terrones Benítez desencadenó una nueva oleada represiva en contra del movimiento agrario y la corriente política dirigida por los comunistas del Partido Durangueño del Trabajo que, por sus alcances y virulencia, provocarían la virtual disgregación de este primigenio movimiento libertario y radical que había emergido en territorio duranguense durante los primeros años del régimen posrevolucionario. 
Las causas y explicaciones del viraje político que se produjo en la entidad a principios del año de 1929, sin duda estuvieron determinadas en gran medida por los cambios ocurridos en la situación política del país y por la forma como éstos repercutieron entre las distintas corrientes políticas locales. La fractura política que se produjo a raíz del asesinato de Obregón, como hemos señalado, generó una modificación sustancial en la orientación y en el funcionamiento del bloque gobernante. Al centralizarse el poder político nacional en manos del general Calles, ahora bajo la forma de "líder máximo de la revolución", se profundizaron los rasgos autoritarios del sistema político y se acentuaron los retrocesos y claudicaciones en el proyecto social del régimen posrevolucionario, rectificaciones puestas en marcha y claramente advertibles desde la etapa final de la gestión presidencial callista. Como es sabido, a partir de 1926 la política agraria de Calles se caracterizó por una drástica disminución en el proceso de restitución y dotación de tierras para la formación de ejidos y se orientó hacia la formación de cooperativas y colonias en manos de propietarios privados. Igualmente, el nacionalismo económico de su gobierno se fue desvaneciendo a partir de los acuerdos y concesiones otorgadas a las empresas petroleras y los grupos financieros extranjeros. ${ }^{43}$ En tanto que debido a su maridaje político con Morones y la CROM, terminó por distanciarse de otros sectores del movimiento obrero y reprimió violentamente a los movimientos huelguísti-

${ }^{43}$ Carr, Izquierda, 1996, p. 54. cos organizados por los sindicatos ajenos a la central "moronista". ${ }^{44}$ Por otra parte, la conformación del Partido Nacional Revolucionario, a la vez que entrañó la inclusión de múltiples formaciones políticas locales y regionales dentro del partido de la revolución mexicana, significó un proceso de persecución, exclusión y destrucción de aquellas fuerzas y vertientes políticas que intentaron mantener su propio perfil y autonomía.

Así, al influjo de las crisis política de 1928-1929 y del reordenamiento en el bloque gobernante, se produjo un viraje derechista del régimen revolucionario, orientación política que caracterizaría a los sucesivos gobiernos del "maximato". Por ende, las claves primeras en el surgimiento del conflicto entre el gobierno local de Terrones Benítez y los "rojos", dirigidos por J. Guadalupe Rodríguez, deben ubicarse como resultantes del giro reaccionario y antiagrarista que se produjo dentro del bloque gobernante en su conjunto, a lo cual habría que agregar la deuda de obediencia y fidelidad que Terrones Benítez contrajo con Calles al concederle éste la gubernatura. Para el abogado duranguense la obtención del cargo fue la medida de equivalencia para abdicar de su declinante agrarismo y su conversión en ejecutor de sus antiguos aliados.

Sin embargo, es necesario apuntar que también en el otro lado se había producido una serie de reposicionamientos políticos. A partir de la crítica al conservadurismo agrarista del gobierno de Calles, la Liga Nacional Cam-

${ }^{44}$ Campa, Testimonio, 1978, p. 33. 
pesina y sus organizaciones regionales fueron radicalizando sus estrategias de lucha para obtener la tierra. Ante la lentitud en los procedimientos de dotación provisional y definitiva, llamaron a los campesinos a no limitar su acción por la vía del trámite legal, sino también a ocupar y tomar las tierras en manos de los terratenientes y a exigir la completa disolución de los latifundios mediante su reparto entre los campesinos pobres y sin indemnización para sus antiguos propietarios. Bajo esta orientación y aprovechando la situación generada por la revuelta de Amaya y los escobaristas, los dirigentes de la Confederación Roja y del Partido Durangueño del Trabajo redoblaron las movilizaciones campesinas por el reparto de tierras y ocuparon varios latifundios propiedad de individuos implicados en la asonada; a la vez, exigieron del nuevo gobierno local celeridad en la solución de las demandas campesinas y el rezago agrario. Así pues, al gobernador Terrones le tocó responder a los reclamos campesinos y enfrentar la acción radicalizada del "agrarismo rojo".

Igualmente, en el ámbito obrero y sindical, la Confederación de Sindicatos de Obreros y Campesinos de Durango radicalizó su discurso y modificó su estrategia de lucha ante las organizaciones obreras oficialistas y la clase patronal. Frente a la degradación sindical y el oportunismo en el que había caído la CROM, la confederación duranguense -al igual que otras agrupaciones obreras del país-, optó por desligarse de esa central y sumarse a la iniciativa lanzada por varios líderes sindicales y dirigentes políticos del Partido
Comunista para constituir una nueva central obrera de carácter nacional. ${ }^{45}$ La agrupación duranguense participó activamente en los trabajos preparatorios desplegados hacia finales de 1928 por un conjunto de organizaciones obreras y campesinas que culminaron en la celebración de la Asamblea de Unificación realizada del 26 al 30 de enero de 1929 en la ciudad de México, de la que surgió la Confederación Sindical Unitaria de México. La nueva organización agrupó a varias decenas de federaciones obreras y campesinas estatales, un importante número de organizaciones sindicales y la Liga Nacional Campesina; proclamó que su membresía era de 116000 obreros y cerca de 300000 campesinos. ${ }^{46}$ El programa de lucha de la CSUM se sintetizó en tres consignas: "Ni un centavo menos de salarios. Ni un minuto más de trabajo con perjuicio de los trabajadores. Ni un obrero menos en las fábricas, talleres o haciendas". ${ }^{47}$ De esta manera y simultáneamente con la intensificación de las movilizaciones campesinas, se radicalizaban las consignas de lucha de la CSOC entre los obreros y sindicatos de Durango a partir de la constitución de la CSUM. ${ }^{48}$

Por otra parte, las organizaciones sociales y los partidos políticos duran-

${ }^{45}$ Ibid., pp. 45-46.

${ }^{46}$ Martínez, Historia, 1985, p. 92

${ }^{47}$ Salazar, Historia, 1938, p. 353.

${ }^{48}$ Además de la Confederación de Obreros y Campesinos de Durango, participaron en la fundación de la CSUM varios representantes de los trabajadores ferrocarrileros de la entidad, principalmente de Durango y Gómez Palacio, a través de la Confederación de Transportes y Comunicaciones. 
guenses dirigidos por los comunistas habían determinado integrarse al frente electoral impulsado por la Liga Nacional Campesina y el Partido Comunista para contender en las elecciones presidenciales del año 1929. En oposición a la estrategia adoptada en la anterior campaña electoral de apoyar al candidato presidencial del bloque gobernante, la izquierda comunista resolvió participar en forma independiente bajo sus propias siglas y programa de gobierno y lanzar su propio candidato a la presidencia de la república, para oponerse tanto a Gilberto Valenzuela como al candidato "callista" que en breve postularía el PNR. Unas semanas antes de que estallara la revuelta escobarista y de que Amaya fuese botado del gobierno local, la Confederación de Sindicatos Obreros y Campesinos de Durango, el Partido Revolucionario Ferrocarrilero de Durango y el Partido Durangueño del Trabajo participaron al lado de otras organizaciones sociales y partidarias, regionales y nacionales, en la conformación del Bloque Obrero y Campesino Nacional, que proclamó como candidato presidencial al general Rodríguez Triana. ${ }^{49}$ Los ejes programáticos aprobados para la campaña electoral del Bloque refrendaron las posiciones izquierdistas que los comunistas habían adoptado en torno a la lucha sindical y agraria. Bajo el lema: "iLa tie-

\footnotetext{
${ }^{49}$ Además del Partido Comunista de México y la Liga Nacional Campesina, participaron en la convención constitutiva del Bloque, el Partido Ferrocarrilero Unitario y sus organizaciones locales, el Partido Unidad Obrera y Campesina de Veracruz, la Confederación Obrera de Occidente, la Federación del Trabajo de Michoacán, entre otros. Véase El Machete, 26 de enero de 1929.
}

rra y las fábricas para los trabajadores! iNo motín político sino revolución social! iObreros y campesinos, uníos!", el BOCN propugnaba también por la disolución del poder legislativo y su sustitución por asambleas de obreros y campesiros; abolición del poder judicial e instauración de consejos civiles y penales; sueldo tope para los funcionarios públicos; dotación de armamento a los campesinos; salario mínimo de dos pesos diarios en todo el país, y disolución de los latifundios. ${ }^{50}$

Diversos autores y analistas que han abordado el estudio de los movimientos sociales y de la izquierda mexicana en la coyuntura política de finales del año 1928 y los primeros meses de 1929, coinciden en sostener que el reposicionamiento político del PC y las nue. vas estrategias que puso en práctica en los distintos frentes de lucha: sindical, campesino y electoral, provinieron de las directrices aprobadas por el VI Congreso de la Comintern (septiembre de 1928) ${ }^{51}$ Afirman que la política "izquierdista" ("ultraizquierdista", según algunos) adoptada por el PC y las organizaciones sociales y partidarias en las que éste influía, derivó del giro radical y sectario que se produjo en la Comintern y que se expresó en el llamamiento

${ }^{50}$ Martínez, Historia, p. 96.

${ }^{51}$ Bajo el influjo de la revolución de octubre de 1917 y el Partido Bolchevique Ruso, surgió en Moscú, en 1919, la III Internacional Comunista. A partir de la fundación de la nueva Internacional Comunista (Comintern) se alentó la formación de los partidos comunistas en un gran número de países de todo el mundo, entre ellos, el Partido Comunista de México, el cual desde su fundación en 1919 quedó adherido a la Comintern. 
que ésta hiciera a los partidos comunistas para profundizar la lucha de clases y buscar una salida revolucionaria ante la crisis mundial del capitalismo. ${ }^{52}$ En suma, señalan que a partir de esa orientación se empujó a los comunistas mexicanos y al movimiento social y político nucleado en torno a éstos hacia posiciones sectarias que luego devinieron en actos de provocación y en un abierto desafío en contra del régimen gubernamental. ${ }^{53}$ Por ende, concluyen que la represión detonada por el gobierno mexicano en contra de los comunistas y sus organizaciones, no fue sino la respuesta hacia su política de instigación y provocación.

Sin embargo, las posiciones expresadas por estos analistas tienden a confundir las causas con los efectos que a la postre generaron el enfrentamiento político entre la corriente comunista y el aparato gubernamental. Un análisis más detenido de los acontecimientos políticos nacionales, así como de los hechos ocurridos en Durango y en otras regiones del país durante los primeros

\footnotetext{
52 Véase Carr, Izquierda, 1996, p. 56; Córdova, Revolución, 1995, pp. 247-248.

${ }_{53}$ Spenser, Triángulo, 1998, p. 206 . Esta autora, además de reiterar la afirmación de que existió un intento insurreccional del PC en la coyuntura del alzamiento escobarista, llega a señalar que la insurrección probablemente fue ordenada por la Comintern. Por otra parte, todas las referencias y testimonios utilizados en torno a los acontecimientos de Durango y en especial sobre J. Guadalupe Rodríguez, provienen y presentan solamente la versión oficial de esa historia. No obstante la parcialidad manifiesta y la poca credibilidad de sus fuentes, a partir de éstas elabora un conjunto de interpretaciones y conclusiones que nos parecen poco consistentes.
}

meses de 1929, nos demuestran que aun antes de que se produjera el giro sectario e izquierdista del $\mathrm{PC}$, y que éste pusiera en práctica las estrategias planteadas por la Comintern que efectivamente orientarían en buena medida la política desplegada por el PC durante los años del "maximato", desde el gobierno ya se había fraguado y determinado movilizar la política de represión dirigida a los movimientos radicales y de izquierda. Creemos que los orígenes reales del conflicto deben ser ubicados y explicados fundamentalmente a partir del giro conservador y derechista del "régimen de la revolución mexicana" al advenimiento del "maximato".

La revisión de los acontecimientos ocurridos en Durango luego del levantamiento escobarista y el examen de la posiciones asumidas por los comunistas locales y las organizaciones en donde éstos poseían una influencia decisiva, nos parece que aportan evidencias y material relevante para conformar un análisis más consistente y de conjunto sobre la actuación de la izquierda mexicana y el movimiento obrero y campesino en la coyuntura política del año 1929.

Desde el momento mismo en que Gualberto Amaya puso en marcha la sublevación "escobarista" en territorio duranguense, la Confederación de Sindicatos Obreros y Campesinos, el Partido Revolucionario Ferrocarrilero y el Partido Durangueño del Trabajo condenaron resueltamente la "asonada reaccionaria y clerical" y llamaron de inmediato a sus miembros a organizarse en destacamentos armados para combatir a las fuerzas infidentes y a los 


\section{SECUENCIA}

1.

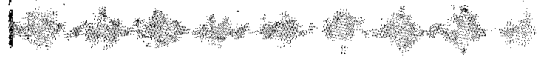

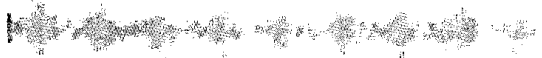

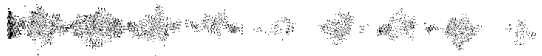

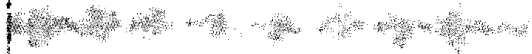

1. (2)

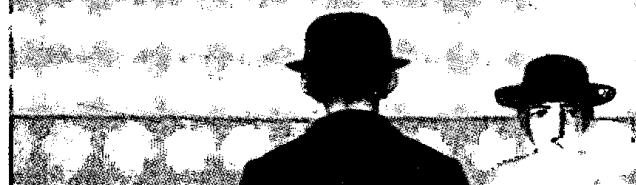

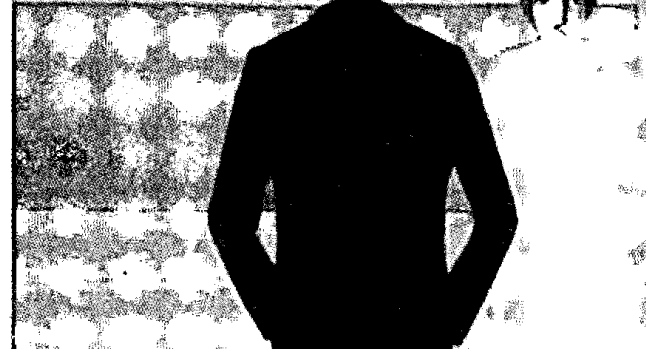

H.t.

W.

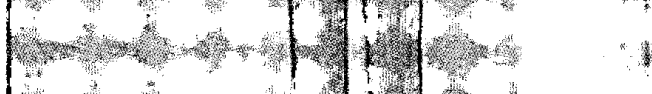

1.

7.

P.

1.

H.

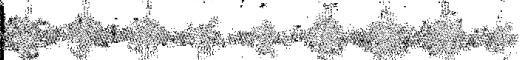

f

站

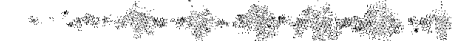

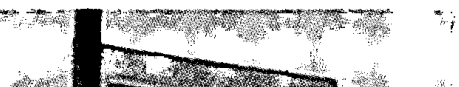

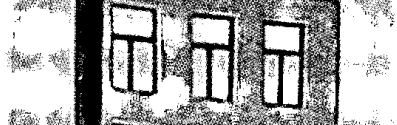

数然

\%

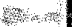
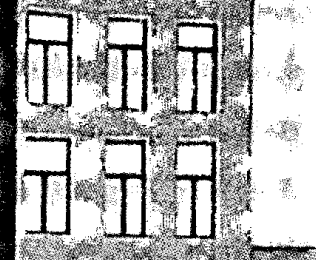

r.

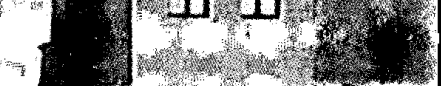

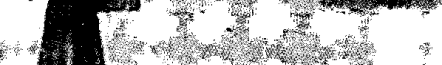

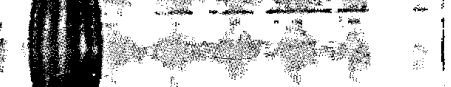

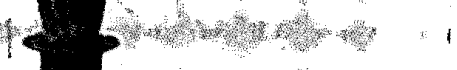

W.

$+4$

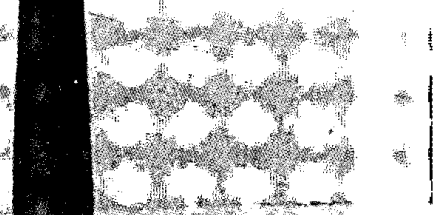

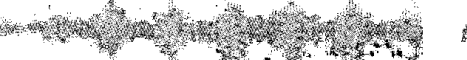


grupos cristeros que se habían sumado a la rebelión. Los dirigentes de la Confederación y el PDT se desplazaron rápidamente hacia las regiones en donde se ubicaban los principales contingentes campesinos y de trabajadores rurales pertenecientes a dichas organizaciones. En cuestión de días aparecieron decenas de guerrillas de los "agraristas rojos", principalmente en la zona llanera y rumbo a la comarca lagunera. La jefatura y conducción del movimiento armado de los campesinos agraristas recayó en manos de su principal dirigente y organizador: J. Guadalupe Rodríguez. ${ }^{54}$ Los destacamentos campesinos adoptaron la táctica militar guerrillera, atacando principalmente la retaguardia de las fuerzas comandadas por Amaya y Urbalejo. La acción de los agraristas resultó vital para que el ejército federal pudiera derrotar a los militares alzados. A consecuencia del sabotaje realizado por los destacamentos campesinos en contra de los puentes y vías férreas, los militares insurrectos no pudieron recibir pertrechos o ser auxiliados con tropas enviadas por el general Escobar desde La Laguna. ${ }^{55}$

Las acciones emprendidas por los confederados y comunistas duranguenses respondían, además, al llamamiento que hiciera la dirección nacional del Partido Comunista (5 de marzo de 1929) a los obreros y campesinos del país para combatir el alzamiento y organizar sus propios contingentes para luchar en contra de la reacción. En dicho manifiesto señalaban que debía exigirse al gobierno federal y a los gobier-

${ }^{54}$ Campa, Testimonio, 1978, p. 68.

${ }^{55}$ Amaya, Gobiernos, 1947, p. 254. nos locales la entrega inmediata de armamento a las organizaciones obreras y campesinas para combatir, junto a las fuerzas leales al gobierno, a las tropas de la rebelión; la depuración inmediata del ejército federal y la eliminación de todos los elementos enemigos de la clase trabajadora; la disolución de las haciendas y latifundios y proceder a la entrega de las tierras y de la maquinaria agrícola entre los peones y campesinos pobres y sin tierra; establecer el control obrero de fábricas y centros industriales a través de la constitución de comités de fábrica para vigilar la producción y hacer respetar los derechos de los trabajadores; reclamar el apoyo para disponer de locales para organizar asambleas y mítines en contra de la rebelión; declarar disueltas y fuera de la ley a las asociaciones clericales y reaccionarias, tales como la Liga Nacional de Defensa Religiosa y los Caballeros de Colón; así como la formación en todo el país de Comités Obreros y Campesinos contra la Reacción. ${ }^{56}$ Por su parte, el gobierno nacional, ante la necesidad de contar con el apoyo de las masas campesinas y obreras y de sus organizaciones para aplastar la sublevación, aceptó la formación y el auxilio de los destacamentos que se organizaron en distintos lugares del país y procedió a dotarlos de armas y municiones.

Mediante la acción mancomunada del ejército federal y las "fuerzas regionales campesinas" integradas por los agraristas, en muy poco tiempo se derrotó a las tropas sublevadas por Amaya y Urbalejo y se logró expulsarlas de la

${ }^{56} \mathrm{El}$ Machete, 9 de marzo de 1929. 
entidad. Hacia finales de marzo de 1929 la asonada escobarista estaba superada, y desde el gobierno federal se habían designado nuevas autoridades civiles y militares. Como ya se ha expuesto, el licenciado Terrones Benítez asumió la gubernatura y el general Manuel Medinaveytia tomó el mando de la Jefatura de Operaciones Militares. Sin embargo, la revuelta de los generales obregonistas había propiciado y favorecido el repunte de la sublevación cristera que venía operando dentro del territorio duranguense. Las incursiones y ataques de las bandas cristeras en contra de poblaciones, ejidos y ciudades se multiplicaron.

La revuelta cristera pudo reactivarse gracias al pacto que habían establecido los principales cabecillas cristeros con Amaya y Urbalejo para luchar mancomunadamente en contra del gobierno federal y los agraristas, así como por el refuerzo de las subvenciones económicas y el apoyo político que diversos individuos y grupos les otorgaban en forma encubierta. La alianza con los cristeros fue buscada por los generales obregonistas desde el inicio de su levantamiento. En un manifiesto dirigido al pueblo de Durango por el general Urbalejo (6 de marzo de 1929), al referirse a los "grupos de gente que se encontraban en las montañas" les indicó que la causa por la que peleaban estaba incluida en las banderas de la rebelión, a la vez que ofrecía otorgarles toda clase de garantías, apoyo y trato de amigos de la causa a todos aquellos que se unieran a sus fuerzas. ${ }^{57}$ Por su parte, el general Amaya, en el transcur-

\footnotetext{
${ }^{57}$ Meyer, Cristiada, 1973, p. 286.
}

so de la revuelta, se desplazó a la sierra para conferenciar con el jefe cristero Acevedo, el cual acampaba al lado de sus fuerzas en las cercanías de la población de El Salto, para acordar la movilización de las huestes cristeras hacia la capital duranguense y planear las acciones de guerra que emprenderían en otras regiones de la entidad, así como para entregarles nuevas dotaciones de dinero y armamento. ${ }^{58} \mathrm{En}$ efecto, gracias a los perterchos recibidos, los rebeldes cristeros lograron ocupar la ciudad de Durango por espacio de un día y medio (del 13 al 14 de marzo), la cual quedó a su alcance luego de que Amaya y sus menguadas tropas la abandonaron ante el inminente arribo del ejército federal.

Por tanto, las tropas federales que habían ocupado la entidad, asi como los destacamentos agraristas, debieron continuar en pie de lucha para contener y aplastar la revuelta que los cristeros mantenían por su cuenta. Ante los llamamientos que el gobierno hizo a las masas campesinas para integrarse a la lucha en contra de la reacción clerical, pronto se multiplicaron los contingentes que demandaron poner las armas en sus manos. Dada la amplitud de su base social y la influencia que habían alcanzado las organizaciones dirigidas por los comunistas entre las masas campesinas, la mayor parte de los contingentes armados que llegaron a organizarse estaban vinculados a la Confederación de Sindicatos Obreros y Campesinos y al Partido Durangueño del Trabajo. Por ende, el movimiento encabezado por los comunistas, los cua.

${ }^{58}$ Amaya, Gobiernos, 1947, p. 256. 
les habían designado como "Estado Mayor" de su milicia a J. Guadalupe Rodríguez, Joaquín Antuna y Sixto Fernández, ${ }^{59}$ se alzó en la entidad como la principal fuerza en contra de la contienda anticristera.

Empero, el movimiento agrarista no sólo se había propuesto participar al lado del gobierno para colaborar en la derrota de Amaya o de las fuerzas cristeras. Desde el inicio de su movilización, los contingentes campesinos incorporaron su propio programa y propósitos de su lucha. Para los dirigentes comunistas no sólo se trataba de derrotar política o militarmente a las fuerzas de la reacción, sino de avanzar en el mejoramiento de las condiciones de existencia de las masas obreras y campesinas. La movilización agrarista debería lograr simultáneamente la destrucción de los latifundios y proceder a su reparto entre los peones y campesinos sin tierras; la restitución de tierras a los pueblos y ejidos que habían sido despojados por los propietarios latifundistas, y garantizar salarios adecuados para los obreros y los trabajadores agrícolas.

Bajo estas directrices, el gobierno local debió enfrentar los reclamos de múltiples grupos campesinos que demandaron la inmediata confiscación y reparto de las propiedades de aquellos individuos que habían participado o apoyado la sublevación de Amaya o que habían sido identificados como patrocinadores de los cristeros. ${ }^{60}$ En

${ }^{59}$ Del gobernador del estado al presidente de la república. Durango, 30 de abril de 1929 , AGN, fondo Emilio Portes Gil, exp. 1/847.

${ }^{60}$ La Federación de Sindicatos Obreros y Campesinos de la Región Lagunera pertene- tanto, otros grupos campesinos ocuparon varios ranchos y haciendas de quienes habían huido o fueron expulsados de la entidad por los cargos arriba senalados. Entre las propiedades tomadas por los agraristas podemos mencionar a la hacienda de Santa Elena en el municipio del Mezquital, propiedad de los españoles Juan e Ignacio del Castillo; dos haciendas propiedad de Luis Gurrola, ubicadas en el municipio de la capital; dos ranchos ganaderos del general Amaya, pertenecientes al municipio de Canatlán; un rancho propiedad del general Urbalejo, ubicado en el municipio de Durango, y una hacienda ubicada en Súchil, propiedad de Miguel Puente. ${ }^{61}$

El despliegue del movimiento campesino y la radicalización de sus exigencias agrarias empezaron a ser vistos con temor y desconfianza no sólo por las clases propietarias, sino además por el gobierno local. Ante el riesgo de que los agraristas siguieran ampliando las demandas de afectación de otros latifundios y propiedades o que procedieran a su ocupación, un gran número de dueños de haciendas recurrieron a Terrones Benítez para demandarle que pusiera fin a las "tropelías y actos fuera de la ley" que, según éstos,

ciente a la Confederación de Durango, solicitó al gobierno expropiar varias haciendas propiedad de extranjeros, entre ellas del español José Cueto, a quien se acusaba de haber apoyado al general Escobar. Federación de Sindicatos Obreros y Campesinos de Durango al ministro de Guerra. Gómez Palacio, Dgo., 21 de marzo de 1929 , en ibid., exp. 3/343.

${ }^{61}$ Del gobernador provisional del estado de Durango al presidente Portes Gil. Durango, 22 de abril de 1929 , en ibid., exp. 3/343. 
venían cometiendo las Defensas Regionales bajo el pretexto de su participación en el aplastamiento de los escobaristas y cristeros, además de exigir su inmediato desarme. Asimismo, denunciaban el "grave peligro" que representaba la creciente y perniciosa difusión de las ideas y de la propaganda comunista entre los campesinos duranguenses, por lo que igualmente exigían cortarla de tajo para impedir la "formación de un infierno bolchevique como el que arruinó a Rusia" ${ }^{62}$

Por su parte, el gobernador Terrones Benítez muy pronto también empezó a distanciarse de sus antiguos aliados y a hacer suyas las mismas críticas e infundios propalados por los terratenientes y los grupos más reaccionarios de la entidad. Ante la disyuntiva de respaldar el movimiento y las demandas de las masas campesinas o garantizar la paz social y la estabilidad del "régimen revolucionario", en los términos políticos dictados por el nuevo "jefe máximo" y que ahora también eran compartidos por las elites duranguenses, el ex constituyente determinó convertirse en la punta de lanza en contra del agrarismo radical y las organizaciones hegemonizadas por los comunistas. Así, a la vez que reconstruía la alianza entre las elites y el "régimen de la revolución" en Durango, alianza que se había deteriorado y puesto en crisis a raíz de los conflictos de los últimos meses, Terrones, de paso, se aprestaba para eliminar a la corriente política y a los dirigentes que lo habían desplazado del liderazgo del movimiento campesino

${ }^{62}$ José Fierro a Terrones Benítez. Rodeo, Durango., 2 de mayo de 1929 , en $i b i d$., exp. 4/565. y que ahora veía como sus principales competidores y adversarios políticos. De esta manera, los contingentes de la Confederación "roja" y del Partido Durangueño del Trabajo pasaron del campo de los aliados al de los enemigos del gobierno duranguense.

Con el propósito de controlar y limitar la acción de los contingentes en armas, el gobernador interino expidió varios manifiestos-circulares a través de los cuales amenazó con recurrir a las fuerzas militares para desarmar a todos aquellos campesinos que utilizaran las armas "para provocar choques por causa de conflictos relacionados con el problema social de tierra o del trabajo". Igualmente decretó la prohibición para efectuar requisiciones de pertrechos de guerra, de forrajes o de cualesquier otro bien, a la vez que exigió "respetar y dar protección" a todas las empresas que constituyeran una fuente de trabajo. En tanto, se ordenó a todos los dirigentes o jefes de las fuerzas agraristas de cada región ponerse bajo el mando de los "comandantes de fuerzas regionales" designados por el gobierno.$^{63}$ En los hechos, tales disposiciones significaban, en primer término, dejar de lado y sin respuesta las demandas y reivindicaciones agrarias que el movimiento campesino había planteado al definir su participación en la lucha antiescobarista y anticristera. En segundo lugar, pretendían someter y desplazar a los dirigentes

${ }^{63}$ Circular número 1. A los jefes de defensas regionales, compuestas por campesinos agraristas del estado de Durango, Alberto Terrones Benítez. Durango, 28 de marzo de 1929, en ibid., exp. 1/847 
agraristas de la conducción de su propio movimiento al intentar ponerlos bajo las órdenes de los jefes designados por el gobierno. Pero sobre todo, transformaban en actos fuera de la ley y delictivos diversas iniciativas y acciones que los agraristas habían llevado a cabo. Es decir, se creaba el marco legal para gobernar la represión.

Simultáneamente, Alberto Terrones desplegaba en forma soterrada ante el gobierno federal una insistente campaña de denuncia e instigación en contra de los comunistas. A través de repetidas comunicaciones dirigidas al presidente de la república y a la Secretaría de Guerra, delató la creciente propaganda y actividades desplegadas por la CSOC y del PDT entre las masas obreras y campesinas y el gran riesgo que ello representaba para la estabilidad social y política de la entidad. Para entonces (abril de 1929), el gobernador duranguense ubicaba en el mismo bando de "traidores de la revolución" a los cristeros, a los escobaristas y a los comunistas. A la vez que informaba que su gobierno estaba dispuesto a obrar con energía y a tomar las medidas que "las circunstancias demandaran" para poner fin a la funesta labor que desarrollaba el grupo de agitadores comunistas dirigidos por J. Guadalupe Rodríguez, ${ }^{64}$ por lo que demandaba al gobierno y al ejército federal adoptar drásticas medidas al respecto.

La acción represiva pronto fue puesta en marcha por el propio gobernador

${ }^{64}$ Alberto Terrones Benítez al presidente Portes Gil. Durango, 18 de abril de 1929, en ibid., exp. 3/343/101-R2. en combinación con el general Medinaveytia, jefe de Operaciones Militares en el estado. Al retornar a la ciudad de Durango la columna campesina integrada por cerca de 700 agraristas bajo el mando de J. Guadalupe Rodríguez y otros líderes comunistas, luego de haber permanecido durante cerca de 20 días en campaña militar en la región del Mezquital para perseguir y derrotar a cerca de 500 cristeros que se habían refugiado en las serranías, ${ }^{65}$ todos los integrantes del destacamento "rojo" fueron desarmados y despojados de sus monturas por el ejército, bajo la acusación de haber cometido actos de "indisciplina en campaña". Además, 131 de ellos fueron acusados penalmente de los delitos de robo y despojo por apoderarse de la caballada de varias haciendas; caballada a la que, además, se denunció con gran enojo y escándalo, le habían puesto el "fierro" con el emblema de la hoz y el martillo. En tanto que J. Guadalupe Rodríguez, Sixto Fernández y Joaquín Antuna fueron encarcelados en el cuartel militar de la capital bajo las mismas acusaciones, más los delitos de sedición e incitación a la rebelión. Todos los cargos y

${ }^{65}$ Del gobernador de Durango al presidente de la república. Durango, 9 de abril de 1929, en ibid., exp. 1/847/421. En esta misiva el gobernador duranguense informa sobre el número de integrantes de la partida agrarista de los comunistas que venían participando en contra de los cristeros en El Mezquital. Tanto el gobernador como el jefe de Operaciones Militares la calculan en cerca de 700 integrantes. Sin embargo, en informes posteriores a la muerte de Rodríguez, Terrones modificará y minimizará el número de efectivos que participaban en los destacamentos de la CSOC y del PDT. 
acusaciones fueron promovidos por el gobierno local. ${ }^{66}$

Frente a las airadas protestas de múltiples grupos campesinos de la CSOC y del PDT por la detención de sus líderes y la intervención de la Liga Nacional Campesina ante las autoridades federales en demanda de su libertad, así como por haberse comprobado la inexistencia de los supuestos delitos cometidos por la columna agrarista, el gobierno local se desistió de las acusaciones formuladas y luego de más de una semana de encarcelamiento tuvo que dejar en libertad a los dirigentes comunistas (26 de abril de 1929). En el propio documento de desistimiento presentado por la Procuraduría de Justicia del Estado se reconoció que el ganado recogido por los agraristas había sido utilizado para dotar de monturas al contingente y que éste provenía de la hacienda de Santa Elena, la cual había sido incautada por el gobierno y los campesinos debido a que sus propietarios fueron identificados como cómplices de la asonada escobarista y además estaban coludidos con los cristeros, y que otros hatos confiscados pertenecían al entonces prófugo general Urbalejo. Igualmente, se aceptó que los actos ejecutados por el contingente agrarista y sus dirigentes no podían ser considerados como delictivos, y mucho menos con el propósito de emprender una sedición. Señalándose, incluso, que dichas acciones resultaban explicables dadas las circunstancias que rodeaban a las

${ }^{66}$ Alberto Terrones Benítez al presidente Emilio Portes Gil. Durango, 30 de abril de 1929, en ibid., exp. 1/847. masas campesinas ante los atropellos de que han sido víctimas por parte de los hacendados y de las autoridades civiles y militares que, violando la ley al pretender cumplir con sus deberes, traicionaron al supremo gobierno. ${ }^{67}$

Al obtener su libertad, los dirigentes del Partido Durangueño del Trabajo, a través de un manifiesto público firmado por Guadalupe Rodríguez, expusieron y denunciaron las que ellos consideraban como las verdaderas causas de su encarcelamiento y en el que alertaron a sus compañeros sobre futuras acciones en contra de su organización:

El día 26 del corriente a las 19 horas salí de la prisión en donde me tenía recluida la reacción por obra de la intriga y la calumnia que los caciques y traidores levantaron en contra mía y de los compañeros Joaquín Antuna y Sixto Fernández. La canalla cobarde que nos ha intrigado en combinación con los caciques católicos de la región llanera que sostuvieron a Urbalejo y Amaya durante su nefasto régimen, ha tratado de echar encima a mí y a mis compañeros todo el lodo que los ahoga a ellos, pero se han puesto en ridículo porque no probaron los cargos calumniosos que levantaron en mi contra, y sí ensenaron la oreja reaccionaria que les es imposible ocultar, ya que su mentalidad y posición económica de pequeños burgueses los obliga a ser forzosamente enemigos de los hombres que en Durango hemos defendido siempre $[\ldots]$ las ideas revolucionarias de nuestra clase obrera y campesina. Nuestro destino

${ }^{67}$ Acta de pedimento del procurador de justicia del estado al juez segundo del ramo penal. Durango, 26 de abril de 1929, en ibid. 
revolucionario nos ha dado una experiencia más en la lucha de clases que sostenemos en contra del capitalismo imperialista, y aprovechamos esa experiencia para revelarles a nuestros compañeros de lucha que [no] solamente la reacción clerical y latifundista se asusta de nuestro distintivo comunista de la hoz y el martillo y nos combate con villanía, sino también los que diciéndose revolucionarios y liberales se han colado en nuestras filas cubiertos como lobos con la piel de oveja para traicionarnos y colaborar con la reacción de todos los matices. Los saludo y quedo vuestro compañero de lucha. ${ }^{68}$

Empero, el retiro de los cargos en contra de los agraristas de la csoc y del PDT, así como la excarcelación de sus dirigentes, no constituyeron sino una aparente y breve tregua por parte del gobierno y la elite terrateniente de Durango para preparar el golpe definitivo. Sólo unos cuantos días después fue encarcelado en Gómez Palacio otro dirigente campesino perteneciente al Partido Durangueño del Trabajo, Juan Montes Vera, al que ahora se acusó de haber proferido en un mitin "graves insultos a los hombres representativos de los movimientos reivindicadores del pueblo mexicano" (Terrones se refería al presidente Portes Gil y por supuesto a él mismo) y de realizar actividades de propaganda comunista entre los miembros del ejército. A partir de este hecho, Terrones Benítez aprovechó la ocasión para reemprender en forma

${ }^{68}$ Partido Durangueño del Trabajo. A todos los compañeros organizados del estado. Durango, 29 de abril de 1929 , en ibid., exp. 4/ 314, f. 8401 . pública su labor de denuncia en "contra de la agitación insana y disolvente de los líderes ultrarradicales en contra de las instituciones", a la vez que llamó abiertamente a todas las autoridades del estado para que siguieran cumpliendo

con su deber de represión de todo movimiento desordenado y desorientador, que resulta verdaderamente criminal en las condiciones por las que atraviesa nuestro país, al desarrollarse esa actividad dentro del elemento proletario. ${ }^{69}$

En franca histeria política, ubicó como enemigos iguales a los elementos "conservadores y a los ultrarradicales":

La nación y principalmente nuestro proletariado mexicano se debate angustiosamente entre dos extremismos que tienen el carácter de verdaderos fanatismos: uno se dirige desde Roma y el otro tiene su asiento en Rusia, ambos forman dos polos opuestos, [pero] se tocan y coinciden no solamente para atacar rudamente y a su modo el gobierno constituido, sino para provocar al pais graves conflictos... Si la nación languidece y si el pueblo trabajador se muere de hambre, no es por culpa del gobierno o por causa de nuestras leyes, es por la acción conjunta de estos proyectos de exterminio que en la actualidad desarrollan cada cual por su lado y a su modo. ${ }^{70}$

Obrando en consecuencia con sus propios llamados para intensificar la

\footnotetext{
${ }^{69}$ Declaraciones de Alberto Terrones Benítez a propósito de la detención de Juan Montes Vera. Durango, 9 de mayo de 1929, en ibid., exp. $1 / 847 / 421$.

${ }^{70} \mathrm{Ibid}$.
} 
represión y el exterminio de la corriente comunista, el ex constituyente Terrones Benítez, en complicidad con el general Medinaveytia, urdieron el complot para eliminar a su principal dirigente, J. Guadalupe Rodríguez, y una vez logrado esto, proseguir con la destrucción del movimiento social y político y de las organizaciones dirigidas por los comunistas duranguenses. Apenas quince días después de haber salido de prisión, el joven profesor comunista y otros dos miembros del PDT, Francisco Ávila y Salvador Gómez, fueron aprehendidos el 12 de mayo por la policía municipal. Guadalupe Rodríguez y Salvador Gómez fueron entregados a las autoridades militares y encarcelados en el cuartel Juárez de la Jefatura de Operaciones. En tanto que Ávila, quien fungía como presidente de la Liga Pro-Luchadores Perseguidos, permaneció detenido en los separos de la Inspección de la Policía Municipal. Dos días después condujeron a los prisioneros a las oficinas de la Comandancia Militar, jefatura en donde fueron informados de los delitos por los que habían sido aprehendidos: robo de parque y armamento del ejército y sedición. Durante el careo correspondiente, Francisco Ávila apareció inusitadamente como testigo de cargo en contra de sus compañeros, declarando que los propios acusados le habían confiado estar comprando parque y armas a un individuo que se encargaba de vigilar uno de los sitios en donde el ejército los almacenaba. La acusación de este delator bastó para que el general Medinaveytia y autoridades militares ordenaran la formación de juicio sumario en contra de los acusados ba- jo el cargo de sedición. Francisco Ávila fue absuelto y puesto en libertad. Ese mismo día (14 de mayo de 1929), el dirigente comunista J. Guadalupe Rodríguez fue fusilado por un pelotón militar en el cuartel Juárez, junto a su compañero Salvador Gómez. ${ }^{71}$

Por su parte, el gobernador Terrones, tres días después de haber sido ejecutado el líder agrarista, informaba al presidente Emilio Portes Gil sobre el "lamentable acontecimiento" en los términos siguientes:

A pesar de que este gobierno obró con la mayor benevolencia en el caso de las graves irregularidades cometidas por los Regionales al mando de J. Guada. lupe Rodríguez[...] sin embargo, [éste] continuó su labor sorda de propaganda entre algunos campesinos que pudieran hacerle eco[...] La forma decidida en que el señor Rodríguez sostuvo su propaganda comunista al grado de recurrir a hechos más graves, que fueron comprobados en esta ciudad por la autoridad militar, ocasionó que fuera ejecutado recientemente, deplorando el gobierno de mi cargo profundamente este acontecimiento, que demuestra hasta dónde pueden llegar los fanatismos y los excesos cuyo desarrollo está dirigido por el elemento comunista hacia acontecimientos que ya en otra ocasión he señalado como de funestas consecuencias para la patria. ${ }^{72}$

No obstante las inumerables con. denas que por todo el país se levanta-

${ }^{71}$ El Machete, 1 de junio de 1929.

${ }^{72}$ Alberto Terrones Benítez al presidente Emilio Portes Gil. Durango, 17 de mayo de 1929, $A G N$, fondo Emilio Portes Gil, exp. 4/314, $f$. 8401. 
ron en contra de Alberto Terrones y el general Manuel Medinaveytia por su responsabilidad en el asesinato del líder campesino comunista y el cúmulo de protestas que se hicieron llegar desde el extranjero al gobierno de Portes Gil por su cómplice pasividad ante la ejecución de Rodríguez Favela, jamás se procedió a investigar y a aclarar el verdadero fondo de los hechos. Además, éstos pronto quedarían subsumidos en el conjunto de los actos represivos que el régimen del "maximato callista" desataría en contra de la izquierda comunista en todo el país. ${ }^{73}$

En tanto, la magnitud del golpe represivo asestado a la dirigencia del movimiento de los obreros y campesinos organizado por los comunistas duranguenses, más la violenta persecución y represión a la que fueron sometidas sus organizaciones tras la muerte y desaparición de su principal líder, a la postre terminarian por fracturarlas y disgregarlas. Los residuos orgánicos de la CSOC y del PDT, tras la exterminación de la corriente comunista y la captación de algunos de sus antiguos líderes por el aparato oficial, serían integrados a la estructura del naciente Partido Nacional Revolucionario. Con ello se liquida-

\footnotetext{
${ }^{73}$ En un gran número de expedientes del fondo Portes Gil del AGN se localizan decenas de documentos que contienen las protestas y denuncias efectuadas por grupos y organizaciones nacionales y del extranjero en relación con los sucesos de Durango y la ejecución de Guadalupe Rodríguez. Como hemos señalado, ello generó una serie de conflictos internacionales para el gobierno mexicano. En especial con la Unión Soviética, lo que finalmente condujo a la ruptura de relaciones diplomáticas entre ambos países.
}

ba este precursor y radical movimiento del campesinado duranguense del siglo XX. Sin embargo, como suele acontecer con todo movimiento social, sus simientes y raíces más profundas no desaparecieron del todo. A la vuelta de unos cuantos años entroncarían y ha: brían de encontrar continuidad en la lucha agraria desplegada por miles de campesinos duranguenses que, otra vez organizados en torno a las diversas vertientes de la izquierda mexicana durante el régimen cardenista, impondrían en la región llanera, en La Laguna y otras regiones de la entidad, el reparto de las haciendas y grandes latifundios.

\section{ARCHIVOS}

AGN Archivo General de la Nación.

AHGED Archivo Histórico del Gobierno del Estado de Durango.

CEMOS Centro de Estudios del Movimiento Obrero y Socialista.

\section{HEMEROGRAFía}

-Periódico Oficial del Gobierno del Estado de Durango, 1928-1930.

-Revista Durangueña, 1928-1929, Durango.

-El Machete, 1927-1929, México.

-El Universal, 1928-1929, México,

-El Nacional Revolucionario, 1929, México.

\section{BIBLIOGRAFÍA}

-Altamirano, Graziella, Rosa Helia Mebius, César Navarro y Guadalupe Villa, Durango. Una bistoria compartida, Instituto Mora, México, 1997. 
-Amaya, Juan Gualberto, Los gobiernos de Obregón, Calles y regímenes "peleles" derivados del callismo, edición del autor, México; 1947.

-Campa, Valentín, Mi testimonio. Memorias de un comunista mexicano, Ediciones de Cultura Popular, México, 1978.

-Carr, Barry, El movimiento obrero y la política en México, 1910-1929, Editorial Era, México, 1981.

, "Los orígenes del Partido Comunista Mexicano", Nexos, núm. 54, junio de 1981.

- La izquierda mexicana a través del siglo $\mathrm{XX}$, Editorial Era, México, 1996.

Córdova, Arnaldo, La clase obrera en la bistoria de México. En una época de crisis (1928-1939), Siglo XXI Editores/IISUNAM, México, 1981.

- La revolución en crisis. La aventura del maximato, Editorial Cal y Arena, México, 1995.

-Elías Calles, Plutarco, Exposición preliminar del Mensaje Presidencial presentado por escrito a las Cámaras federales $y$ discurso del señor presidente de la república ante el Congreso nacional, el primero de septiembre de 1928, Talleres Gráficos de la Nación, México, 1928.

-Garrido, Luis Javier, El partido de la revolución institucionalizada. La formación del nuevo Estado en México. 1928-1945, Siglo XXI Editores, México, 1985.

-Katz, Friedrich, Pancho Villa, Editorial Era, México, 1998, 2 vols.

-Loyola Diaz, Rafael, La crisis ObregónCalles y el Estado mexicano, Siglo XXI Editores, México, 1987.
-Martínez Verdugo, Arnoldo, La bistoria del comunismo en México, Editorial Grijalbo, México, 1985.

-Meyer, Jean, La Cristiada. La guerra de los cristeros, Siglo XXI Editores, México, 1973, vol. 1.

-Meyer, Lorenzo, Rafael Segovia y Ale. jandra Lajous, Historia de la revolución mexicana. 1928-1934. Los inicios de la institucionalización, El Colegio de México, México, 1978, vol. 12.

-Neymet, Marcela de, Cronologia del Partido Comunista Mexicano, Ediciones de Cultura Popular, México, 1981.

-Peláez, Gerardo, Partido Comunista Me. xicano, 60 años de bistoria, Universidad Autónoma de Sinaloa, México, 1980, 2 vols.

-Portes Gil, Emilio, Quince años de política mexicana, Ediciones Botas, México, 1941.

-Rouaix, Pastor, La revolución maderista y constitucionalista en Durango, Editorial Cultura, 1931.

-Salazar, Rosendo, Historia de las luchas proletarias de México. 1923-1936, Editorial Avante, México, 1938.

-Silva Herzog, Jesús, Una vida en la vida de México, Siglo XXI Editores, México, 1993.

-Spenser, Daniela, El triángulo imposible. México, Rusia Soviética y Estados Unidos en los años veinte, CIESAS/Miguel Ángel Porrúa, México, 1998.

-Taibo II, Paco Ignacio, Los bolshevikis. Historia narrativa sobre los origenes del comunismo mexicano, Joaquín Mortiz, México, 1985.

-Terrones Benitez, Alberto, Anecdotario durangueño, Casa de la Cultura, Gómez Palacio, Durango, 1985. 


\section{SECUENCIG}

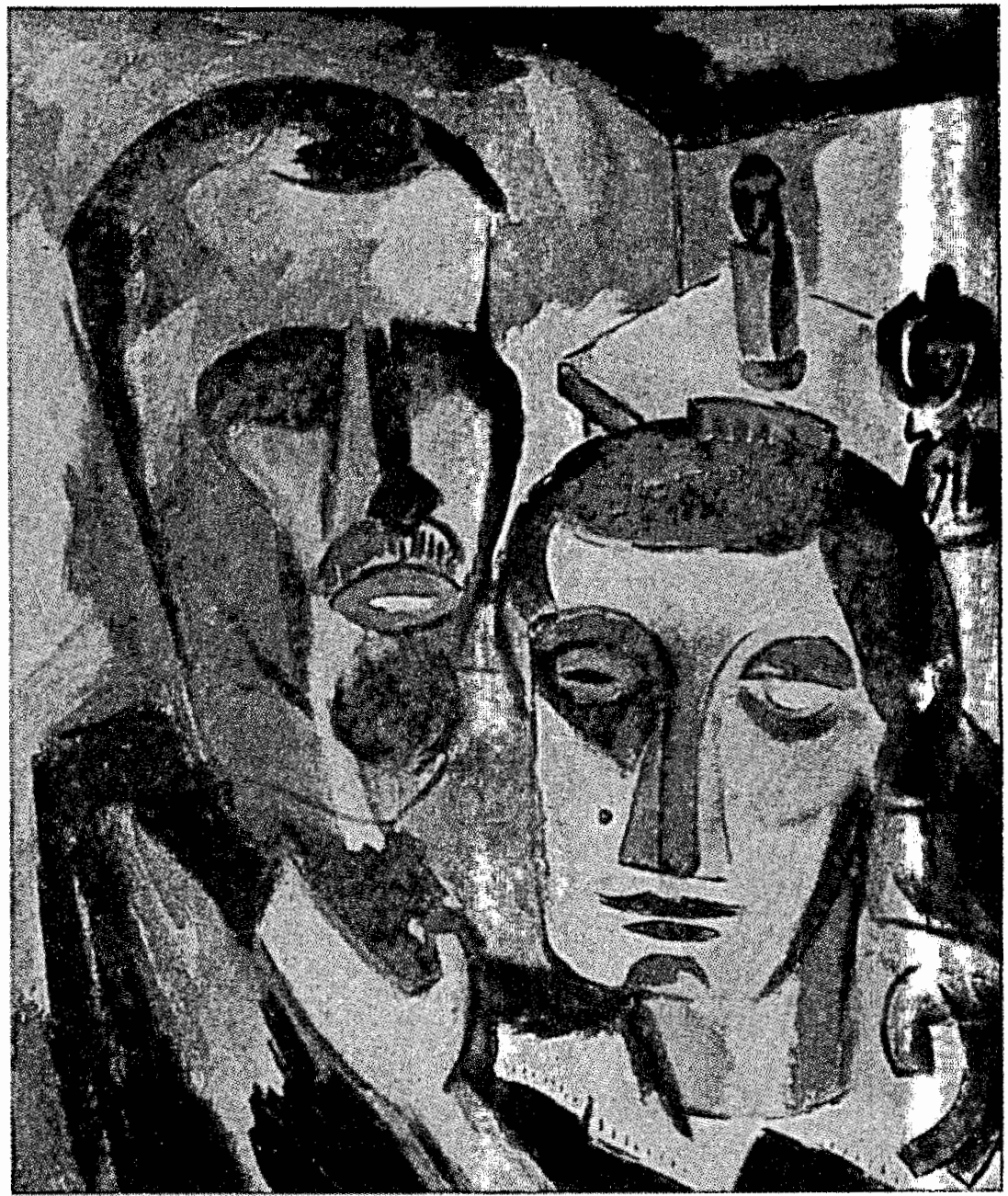

